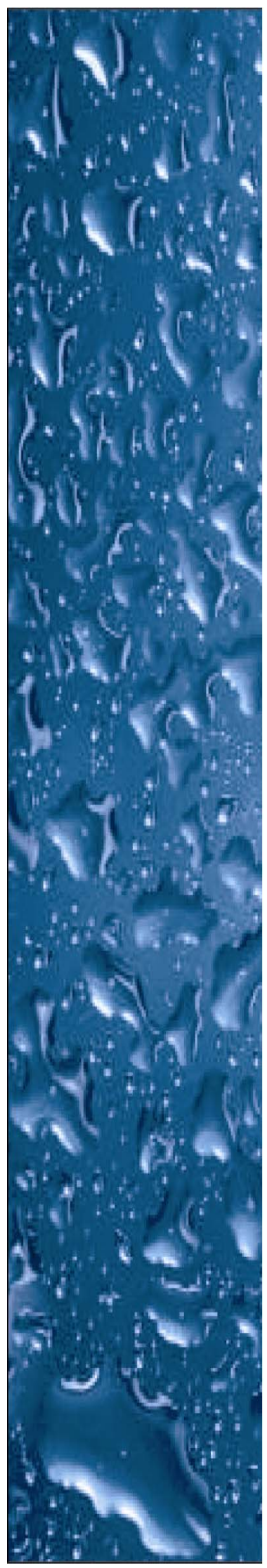

ORNL/Sub-01-4000025209

Field Test and Performance Verification: Integrated Active Desiccant Rooftop Hybrid System Installed in a School

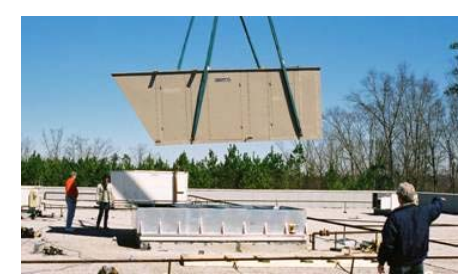

Final Report: Phase 4a

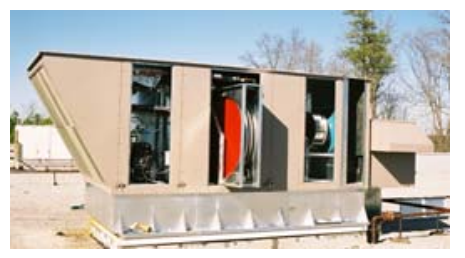

J. Fischer and J. Sand

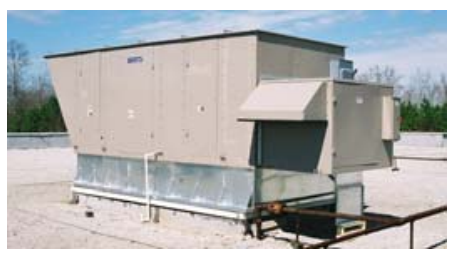

November 2005

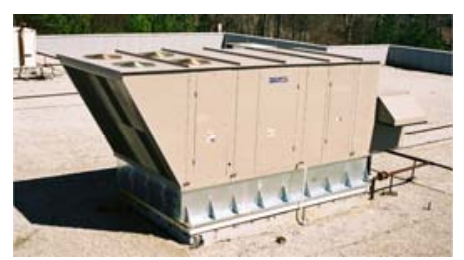




\section{DOCUMENT AVAILABILITY}

Reports produced after January 1, 1996, are generally available free via the U.S. Department of Energy (DOE) Information Bridge:

Web site: http://www.osti.gov/bridge

Reports produced before January 1, 1996, may be purchased by members of the public from the following source:

National Technical Information Service

5285 Port Royal Road

Springfield, VA 22161

Telephone: 703-605-6000 (1-800-553-6847)

TDD: 703-487-4639

Fax: 703-605-6900

E-mail: info@ntis.fedworld.gov

Web site: http://www.ntis.gov/support/ordernowabout.htm

Reports are available to DOE employees, DOE contractors, Energy Technology Data Exchange (ETDE) representatives, and International Nuclear Information System (INIS) representatives from the following source:

Office of Scientific and Technical Information

P.O. Box 62

Oak Ridge, TN 37831

Telephone: $865-576-8401$

Fax: 865-576-5728

E-mail: reports@adonis.osti.gov

Web site: http://www.osti.gov/contact.html

This report was prepared as an account of work sponsored by an agency of the United States government. Neither the United States government nor any agency thereof, nor any of their employees, makes any warranty, express or implied, or assumes any legal liability or responsibility for the accuracy, completeness, or usefulness of any information, apparatus, product, or process disclosed, or represents that its use would not infringe privately owned rights. Reference herein to any specific commercial product, process, or service by trade name, trademark, manufacturer, or otherwise, does not necessarily constitute or imply its endorsement, recommendation, or favoring by the United States government or any agency thereof. The views and opinions of authors expressed herein do not necessarily state or reflect those of the United States government or any agency thereof. 


\title{
Field Test and Performance Verification: Integrated Active Desiccant Rooftop Hybrid System Installed in a School
}

\section{Final Report: Phase 4a}

\author{
November 2005 \\ J. Fischer \\ SEMCO, Inc. \\ J. Sand \\ Oak Ridge National Laboratory \\ Engineering Science and Technology Division
}

Prepared by

SEMCO, Inc.

\author{
for \\ OAK RIDGE NATIONAL LABORATORY \\ Oak Ridge, Tennessee \\ managed by \\ UT-BATTELLE, LLC \\ for the \\ U.S. DEPARTMENT OF ENERGY \\ under contract DE-AC05-00OR22725
}





\section{CONTENTS}

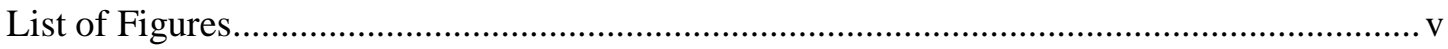

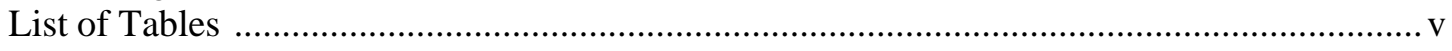

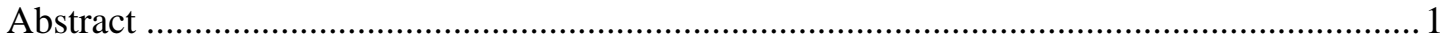

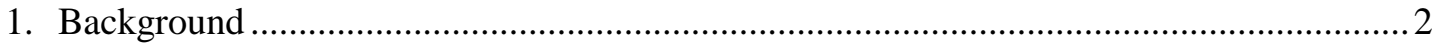

1.1 Using a VAV System to Serve Multiple Spaces within a School Facility ...................2

1.2 IAQ and Humidity Problems Encountered at the School Investigated ........................ 3

2. Retrofit Installation of Integrated Active Desiccant Rooftop Unit ....................................5

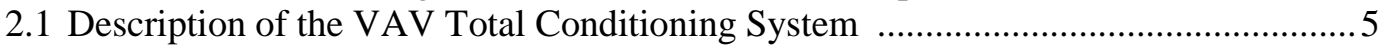

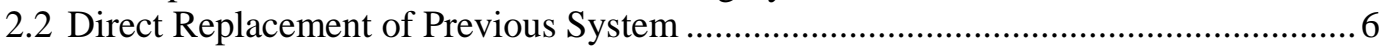

2.3 Benefits Realized by Applying the IADR as a VAV System …...............................

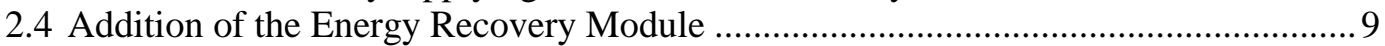

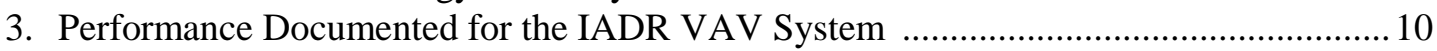

3.1 Temperature and Humidity Control Realized.......................................................... 10

3.2 Higher Thermostat Settings Associated with Improved Humidity Control ................. 12

3.3 Energy Efficiency Observed with the IADR Hybrid System Integration ..................13

3.3.1 Reduction in Tons of Cooling Capacity Required ........................................... 13

3.3.2 Higher Cooling Side Efficiency Due to Variable-Speed Compressor................ 13

3.3.3 Elimination of VAV Box Reheating Requirements ....................................... 14

3.3.4 Reduced Energy Use Associated with Higher Space Temperature

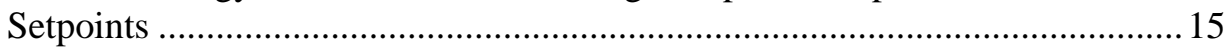

3.3.5 Integrated Energy Recovery Module Impact ............................................ 15

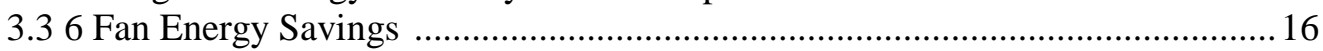

3.4 Heating Mode Operation .................................................................................... 17

4. Indoor Air Quality Investigation-Georgia Tech Research Institute .............................. 19

4.1 $\mathrm{CO}_{2}$ Data Measured before and after Retrofit ..................................................... 19

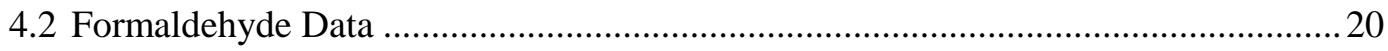

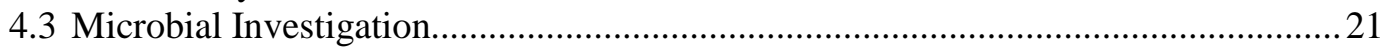

5. Customer Feedback Regarding the Effectiveness of the Pilot Installation ...................... 22

6. Installation Cost Comparison: IADR VAV vs. Conventional Systems .............................23

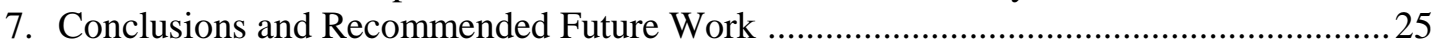

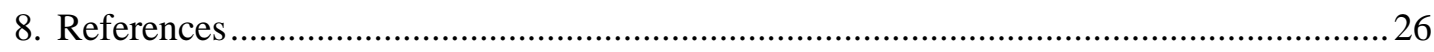

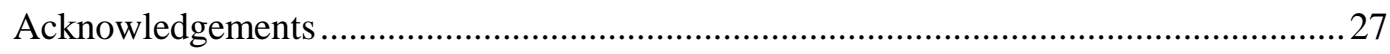

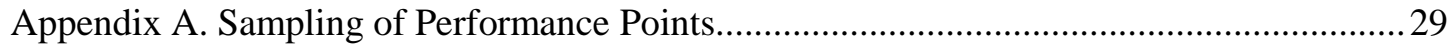

Appendix B. Letter from Cobb County School District ....................................................... 31 


\section{FIGURES}

A.1 The IADR system being installed.

1. HVAC loads for a typical classroom designed in accordance with ASHRAE 62

. Schematic example of IADR applied as a total conditioning system 4

3. Previous conventional system being replaced by the IADR and curb adapter

4. The DDC/data acquisition compartment, desiccant wheel, and service access of the IADR unit

5. The regeneration side of the IADR and integrated recovery module

6. Sample of the return air plenum temperature and humidity data provided by the DDC system

. Sample of classroom humidity data collected by Georgia Tech Research Institute before and after the IADR retrofit

Sample of the return air humidity control and supply dewpoint delivered

\section{by the IADR}

9. Sample of classroom temperature data collected by Georgia Tech Research Institute before and after the IADR retrofit

10. Summary of DOE 2.1 modeling to estimate the increase in cooling energy cost as the thermostat setting is incrementally reduced from $75^{\circ} \mathrm{F}$....

11. Sample performance of the total energy recovery module integrated into the IADR system for the school pilot project.

12. Sample performance of the IADR as it responds to the control system's request to accommodate both heating and cooling conditions over one 24-hour period

13. Carbon dioxide data collected by Georgia Tech Research Institute for classrooms before and after the IADR retrofit

14. Formaldehyde data collected by Georgia Tech Research Institute before and after the IADR retrofit

\section{TABLES}

1. VAV box sizing and list of zones served by the IADR VAV system for the pilot project

2. Comparison of cooling capacity required for the IADR and for a customized packaged unit without recovery

3. Comparison of cooling efficiency (EER) of the IADR and a conventional rooftop unit at part-load conditions based on field and laboratory test data

4. Comparison of costs of the IADR and conventional rooftop units. 


\begin{abstract}
This report summarizes the results of a field verification pilot site investigation that involved the installation of a hybrid integrated active desiccant/vapor-compression rooftop heating, ventilation, and air-conditioning (HVAC) unit at an elementary school in the Atlanta Georgia area. For years, the school had experienced serious humidity and indoor air quality (IAQ) problems that had resulted in occupant complaints and microbial (mold) remediation. The outdoor air louvers of the original HVAC units had been closed in an attempt to improve humidity control within the space.

The existing vapor compression variable air volume system was replaced by the integrated active desiccant rooftop (IADR) system that was described in detail in an Oak Ridge National Laboratory (ORNL) report published in 2004 (Fischer and Sand 2004).

The IADR system and all space conditions have been monitored remotely for more than a year. The hybrid system was able to maintain both the space temperature and humidity as desired while delivering the outdoor air ventilation rate required by American Society of Heating, Refrigerating and Air-Conditioning Engineers Standard 62. The performance level of the IADR unit and the overall system energy efficiency was measured and found to be very high.

A comprehensive IAQ investigation was completed by the Georgia Tech Research Institute before and after the system retrofit. Before-and-after data resulting from this investigation confirmed a significant improvement in IAQ, humidity control, and occupant comfort. These observations were reported by building occupants and are echoed in a letter to ORNL from the school district energy manager (see appendix).

The IADR system was easily retrofitted in place of the original rooftop system using a custom curb adapter (Figure A.1). All work was completed in-house by the school's maintenance staff over one weekend. A subsequent cost analysis completed for the school district by the design engineer of record concluded that the IADR system being investigated was actually less expensive to install than other less-efficient options, most of which were unable to deliver the required ventilation while maintaining the desired space humidity levels.
\end{abstract}

Figure A.1. The IADR system being installed on the footprint used by a conventional rooftop HVAC unit at the Georgia school facility.

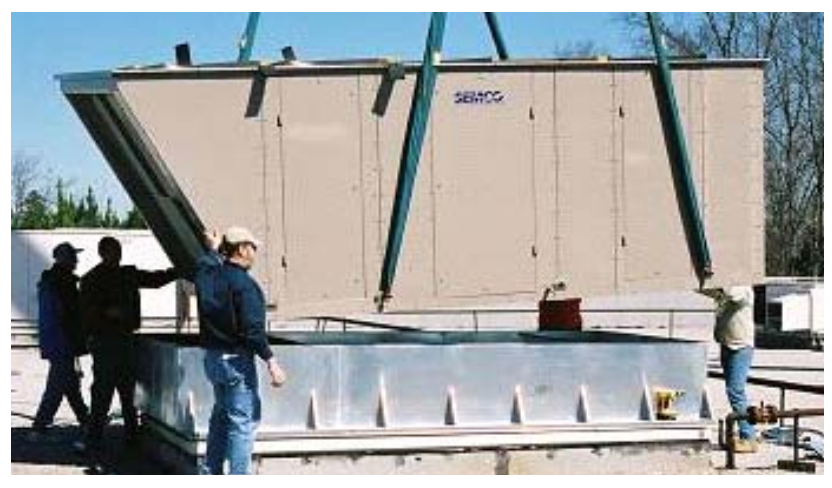




\section{BACKGROUND}

According to the U.S. General Accounting Office, over 30\% of school facilities are experiencing indoor air quality (IAQ) problems (GAO 1996). American Society of Heating, Refrigerating and AirConditioning Engineers (ASHRAE) Standard 62 has addressed this problem by requiring that outdoor air be delivered to school classrooms on a continuous basis while recommending that the space relative humidity be maintained below approximately 60\% (ASHRAE 2004).

Designing cost-effective, energy-efficient systems that can accommodate high percentages of outdoor air without creating humidity control problems presents a significant challenge to the design community. Extended periods of high humidity within a school facility have been shown to result in occupant discomfort, increased energy consumption (as thermostat settings are lowered to battle humidity), and, potentially, more serious microbial problems. Very low humidity levels, which may occur during the heating season when high quantities of outdoor air are delivered to a space, have been linked to higher absentee levels in schools.

A comprehensive IAQ research program co-funded by the U.S. Department of Energy (DOE) and SEMCO, Inc., and completed by Georgia Tech Research Institute (GTRI) and Georgia State University involved 10 schools sampled over a 2-year period. It documented the importance of complying with ASHRAE 62, Ventilation for Acceptable Indoor Air Quality, in designing and operating school facilities. The research also concluded that schools equipped with energy-efficient desiccant-based systems were effective in delivering the outdoor air ventilation rates and humidity control desired. These findings were summarized in a 2003 ASHRAE Journal article (Fischer and Bayer 2003).

Although this research clearly established many benefits offered by the desiccant-based system evaluated, many school districts continue to ignore the building code ventilation requirements and/or sacrifice energy efficiency and humidity control. The primary reason for these compromises is the desire to minimize first cost. A common statement of the persons responsible for designing and building school facilities is that the funding for construction costs is limited, while funds for operation (utilities) are considered unlimited and are controlled by a separate department.

The effective desiccant-based total energy recovery systems highlighted in the ASHRAE Journal article were installed as dedicated outdoor air systems (DOASs), which required additional ductwork to and from the energy recovery system in addition to separate packaged equipment to heat and cool the space. This approach provides ideal IAQ and very low operating cost when the appropriate DOAS is used. However, the first cost may be considerably higher than the amount of money many school facilities make available for mechanical air-conditioning systems.

Therefore, there is a continued desire to identify mechanical system designs that will allow for compliance with the ASHRAE 62 ventilation standard, control space humidity, and operate energyefficiently while simultaneously reducing project first cost.

\subsection{Using a VAV System to Serve Multiple Spaces within a School Facility}

One effective way to lower the first cost of the mechanical system within school facilities is to use one large system to serve multiple spaces. Since the loads within these spaces vary widely, a variable-air-volume (VAV) system must be employed to allow for individual space temperature control when a large central system is employed.

Because only one duct system is required, VAV boxes are inexpensive, and one large system is less costly than numerous smaller systems, this approach is considered by many designers to be the most cost-effective way to effectively condition school facilities, provided that packaged direct exchange (DX) rooftop systems can be used. Despite the first-cost benefit, this approach often is not used because of the performance limitations of packaged VAV systems. They cannot consistently provide comfortable low-humidity conditions during the summer cooling season while delivering the 
high proportion of outdoor air required by a school unless the cooling capacity is over-sized and zone reheat boxes are used. The latter option significantly raises operating costs, is not allowed by the ASHRAE 90.1 energy standard (ASHRAE 2001), and eliminates much of the first-cost advantage offered by the VAV approach.

\subsection{IAQ and Humidity Problems Encountered at the School Investigated}

An elementary school constructed in Atlanta used a conventional packaged VAV air-handling system to condition 19 zones that involved classrooms, hallways, and storage rooms. In an attempt to reduce cost, the design did not use VAV boxes that included zone reheating. Over the years, various operational problems were experienced at this school facility. As a result of consistent IAQ and comfort complaints, all of the outdoor air was shut off to the systems and commercial dehumidifiers were installed in many classrooms. Despite these alterations that compromised IAQ, occupants remained uncomfortable and the cost of operation was very high. In addition, microbial (mold and mildew) problems also were encountered.

The units selected for this facility did not have the cooling capacity necessary to accommodate the outdoor air volume required without delivering leaving coil temperatures in the range of $62^{\circ} \mathrm{F}$. At this temperature, the space could be adequately cooled, but the resulting relative humidity levels in the conditioned space remained above $70 \%$. When the outdoor air dampers were closed, the delivered coil temperatures dropped to approximately $55^{\circ} \mathrm{F}$. The lower temperature helped improve space humidity control, but the classrooms were often over-cooled, even at the minimum box settings. As the airflow was reduced, the latent fraction (dehumidification capacity) was proportionally reduced so that humidity remained high while IAQ degraded. Before the installation of commercial dehumidifiers, mold routinely would grow on the carpeting and ceiling tiles.

A careful design review, conducted by an engineering consultant experienced in evaluating latent as well as sensible loads, concluded that a successful VAV design would require an unconventional packaged system. The load analysis confirmed that the supply air conditions needed by the VAV boxes selected were approximately a $60^{\circ} \mathrm{F}$ temperature at a $50^{\circ} \mathrm{F}$ dewpoint (humidity content). Naturally, the new system would also have to accommodate the ventilation air required by ASHRAE 62 and incorporate modulating refrigeration capacity control to avoid re-evaporation of condensed moisture from the cooling coil associated with a cycling compressor.

As shown in Figure 1, the engineering analysis determined that when the loads are accurately evaluated for a typical classroom it becomes clear that much of the total cooling load is latent. Based upon the data presented in Figure 1, a classroom served by $1100 \mathrm{cfm}$ of supply air would require a delivered air temperature of approximately $60^{\circ} \mathrm{F}$. However, the dewpoint required to process the indoor latent load would be $50^{\circ} \mathrm{F}$. One key advantage of delivering the supply air at approximately $60^{\circ} \mathrm{F}$ is that when all the students leave the room on a rainy day, the box can reduce the total airflow to the minimum setting of approximately $600 \mathrm{cfm}$, and a teacher grading papers will remain comfortable without the necessity of reheat in the VAV box.

Correctly analyzing the loads within the various zones of a school facility and matching the delivered air conditions to those loads, specifically the temperature and humidity conditions needed (sensible heat ratio), is perhaps the most important factor in trying to design a successful VAV HVAC system. The IADR investigated as part of this research site has unique operational capabilities to meet these challenges. These capabilities are summarized in Section 2.3 of this report. 
Case 2: Dewpoint Design, Moderate Activity, Efficient Lighting

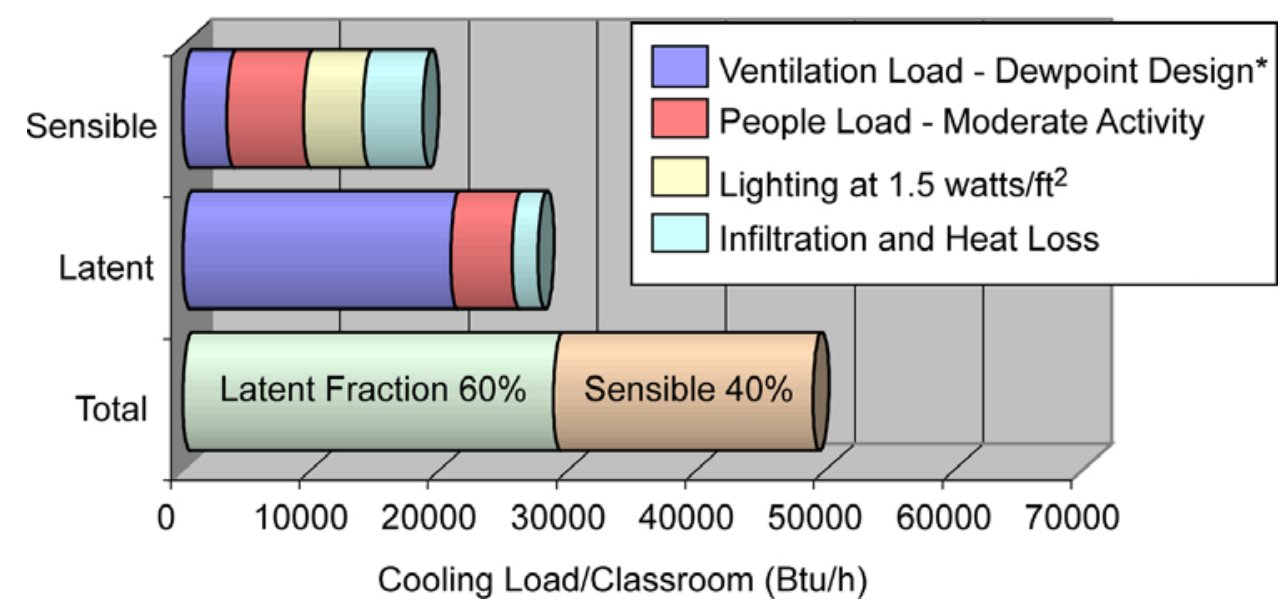

Figure 1. HVAC loads for a typical classroom designed in accordance with ASHRAE 62. 


\section{RETROFIT INSTALLATION OF AN INTEGRATED ACTIVE DESICCANT ROOFTOP UNIT}

The IADR system (Fischer and Sand 2004) was selected to resolve the problems encountered in the Atlanta school. The system was appropriate because it could accommodate a high percentage of outdoor air (up to $100 \%$ ); could deliver the air at the $60^{\circ} \mathrm{F}$ dry bulb, $50^{\circ} \mathrm{F}$ dewpoint condition needed; and uses a variable-speed compressor for ideal capacity control.

In addition, the IADR system is capable of operating as a true VAV system, varying the amount of air across the cooling coil to provide significant fan energy savings as the space-mounted VAV boxes close. The previous system needed to maintain a constant airflow across the DX cooling coil although the amount of air delivered to the space varied. The IADR can be operated as a total conditioning system, handling all the ventilation, space cooling, and heating needs and controlling space humidity in one integrated system.

\subsection{Description of the VAV Total Conditioning System}

When applied in the total conditioning mode (Figure 2), the IADR system delivers a constant quantity of outdoor air, while varying the amount of supply and recirculated air in the proportions needed to satisfy the cooling and heating requirements of the occupied space. The variable-speed vapor compression cooling and active desiccant wheel sections work in tandem and are optimized to control the sensible and latent loads independently. The IADR system therefore has the unique capability to deliver the specific temperature and humidity necessary to maintain the desired space condition — variable sensible heat ratio without the use of parasitic reheat.

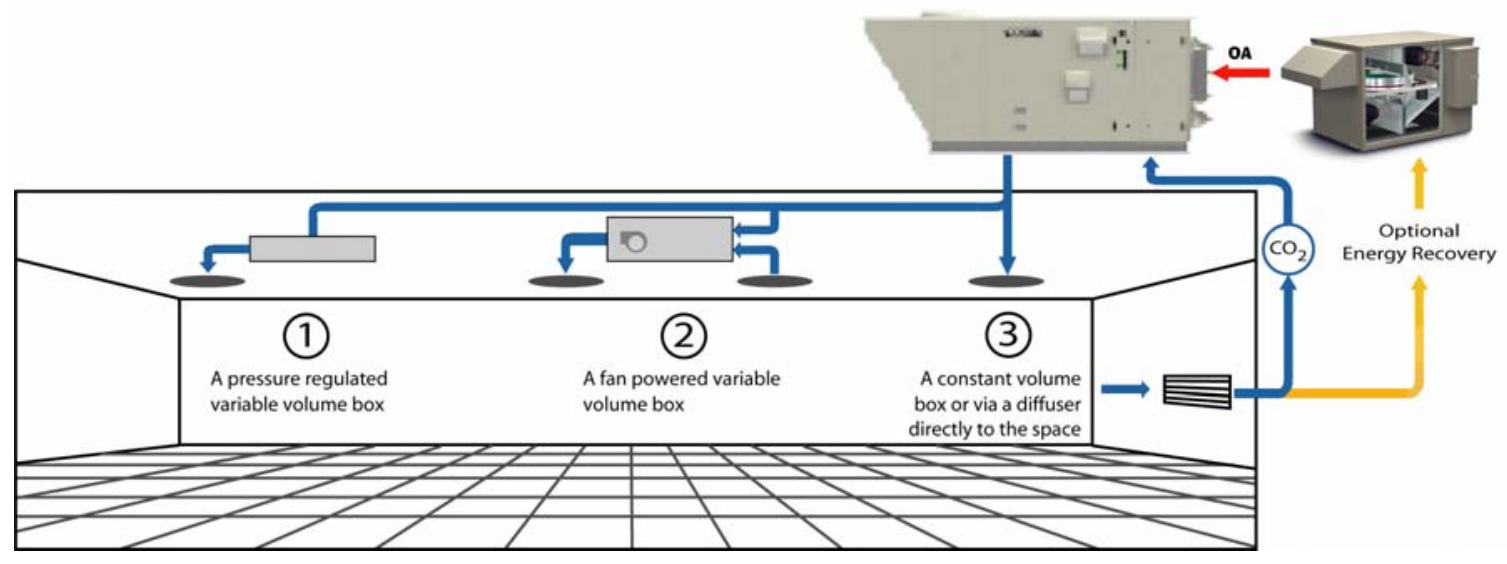

Figure 2. Schematic example of IADR applied as a total conditioning system (as per school pilot).

The variable airflow capability associated with an inverter-driven supply blower on the IADR also allows for the use of either demand control ventilation (based on $\mathrm{CO}_{2}$ monitoring) or a simple time schedule to adjust the amount of outdoor air delivered to the occupied space.

At this school pilot site, a total of 19 zones were conditioned. Each zone was fitted with a variable volume box that was operated as part of a variable volume and variable temperature supply system (VVT). Since the IADR system had the capability to independently control the supply air temperature and humidity level, both of these conditions were monitored and adjusted to optimize the conditions delivered to the space. The significant advantage offered by a VVT system approach is that it 
minimizes or eliminates (as in this case) the need for parasitic reheat at the individual VAV boxes during the cooling mode. Each VAV box contains a direct digital controller (DDC) and an airflow monitor that communicates with both the space thermostat and the main control logic board installed in the IADR system. Return air enters the IADR by way of a ceiling plenum that draws air from each floor of the school facility. The dewpoint of this combined return air stream is used to determine the supply air dewpoint needed to maintain a relative humidity of $50 \%$ in the occupied classrooms. All conditions within the IADR and the various subcomponents were monitored and trended through the combination DDC - data acquisition system.

The temperature of each individual zone was also monitored and trended, as was the total airflow delivered from the VAV boxes or the IADR box to each space. Thus it was simple to document that no space was operated outside the desired thermostat set point range.

As shown in Table 1, the spaces served by the IADR include eight classrooms, three restrooms, three teacher workrooms, three storage rooms, and two hallways. Table 1 refers to VVT boxes to denote that the VAV boxes are operated as part of a VVT system design.

Table 1. VVT box sizing and listing of zones served by the IADR system for the pilot project

\begin{tabular}{|c|c|c|c|c|c|c|c|}
\hline \multirow[t]{2}{*}{$\begin{array}{c}\text { VVT box } \\
\text { designation }\end{array}$} & \multirow[t]{2}{*}{ Zone served } & \multirow[t]{2}{*}{$\begin{array}{c}\text { Reheat in } \\
\text { box }\end{array}$} & \multicolumn{2}{|c|}{$\begin{array}{c}\text { Air flow } \\
\text { (cfm) }\end{array}$} & \multirow{2}{*}{$\begin{array}{c}\text { Inlet diam } \\
\text { (in.) } \\
\end{array}$} & \multirow{2}{*}{$\begin{array}{l}\text { Outlet size } \\
\text { diam (in.) }\end{array}$} & \multirow{2}{*}{$\begin{array}{c}\text { Air valve } \\
\mathbf{P} \text { (in.) }\end{array}$} \\
\hline & & & Design & Min & & & \\
\hline VVT5-1 & Restroom 1 & Not required & 265 & 42 & 5 & 5 & 0.21 \\
\hline VVT5-2 & Classroom 1 & Not required & 822 & 375 & 9 & 9 & 0.13 \\
\hline VVT5-3 & Classroom 2 & Not required & 964 & 375 & 9 & 9 & 0.18 \\
\hline VVT5-4 & Storage 1 & Not required & 111 & 18 & 4 & 4 & 0.09 \\
\hline VVT5-5 & Restroom 1 & Not required & 206 & 33 & 5 & 5 & 0.13 \\
\hline VVT5-6 & $\begin{array}{c}\text { Teacher } \\
\text { workroom } 1\end{array}$ & Not required & 160 & 26 & 4 & 4 & 0.19 \\
\hline VVT5-7 & Classroom 3 & Not required & 822 & 375 & 9 & 9 & 0.13 \\
\hline VVT5-8 & Classroom 4 & Not required & 964 & 375 & 9 & 9 & 0.18 \\
\hline VVT5-9 & Hallway 1 & Not required & 434 & 69 & 7 & 7 & 0.10 \\
\hline VVT5-10 & $\begin{array}{c}\text { Teacher } \\
\text { workroom } 2 \\
\end{array}$ & Not required & 265 & 42 & 5 & 5 & 0.21 \\
\hline VVT5-11 & Classroom 5 & Not required & 822 & 375 & 9 & 9 & 0.13 \\
\hline VVT5-12 & Classroom 6 & Not required & 822 & 375 & 9 & 9 & 0.13 \\
\hline VVT5-13 & Storage 2 & Not required & 98 & 16 & 4 & 4 & 0.07 \\
\hline VVT5-14 & $\begin{array}{c}\text { Teacher } \\
\text { workroom } 3 \\
\end{array}$ & Not required & 185 & 30 & 5 & 5 & 0.10 \\
\hline VVT5-15 & Storage 3 & Not required & 80 & 13 & 4 & 4 & 0.05 \\
\hline VVT5-16 & Classroom 7 & Not required & 822 & 375 & 9 & 9 & 0.13 \\
\hline VVT5-17 & Classroom 8 & Not required & 803 & 375 & 9 & 9 & 0.12 \\
\hline VVT5-18 & Restroom 2 & Not required & 378 & 60 & 7 & 7 & 0.08 \\
\hline VVT5-19 & Hallway 2 & Not required & 434 & 69 & 7 & 7 & 0.10 \\
\hline
\end{tabular}

Whenever a conditioned exhaust air path is available (which is usually the case in school facilities), total energy recovery (a passive desiccant wheel) can be incorporated into the ventilation air pretreatment process to significantly increase the overall operating efficiency. This option was incorporated into the IADR system installed at the Atlanta school. 


\subsection{Direct Replacement of Previous System}

Unlike previous desiccant-based systems that are most often applied as DOASs, the IADR can be installed as a direct replacement for a conventional rooftop unit, using the same roof penetration, ductwork, VAV boxes, and space sensors. Figure 3 shows the original packaged unit that was removed and the IADR system and custom curb adapter used for this retrofit installation.
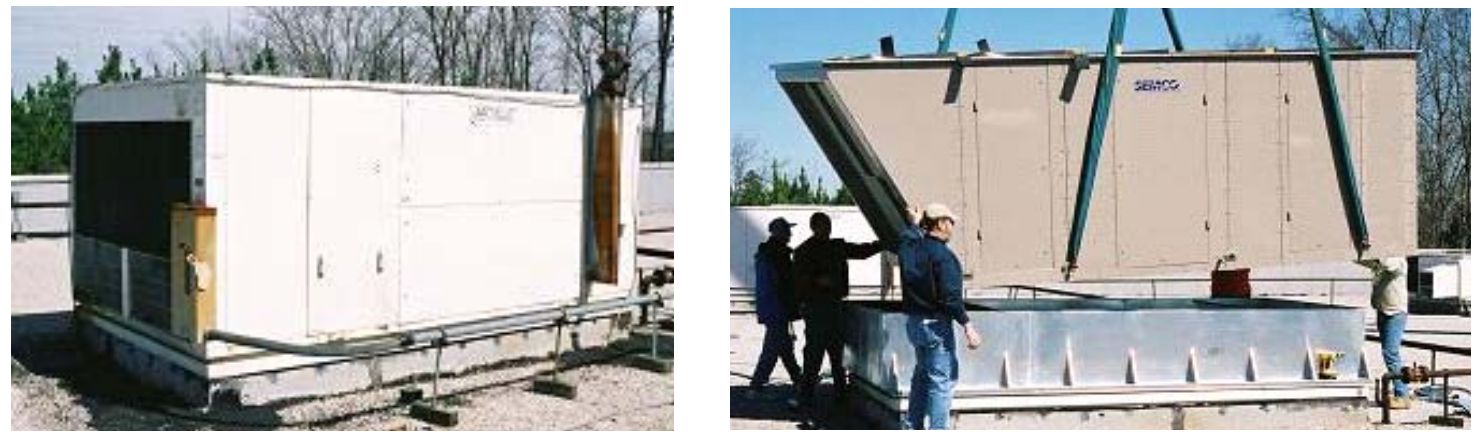

Figure 3. Previous conventional system (left) being replaced by the IADR and curb adapter.

Although the IADR system installed provides 50\% more cooling and dehumidification capacity than the original 30-ton unit that it replaced, and the IADR incorporates both the vapor compression and active desiccant sections, the new hybrid system is essentially the same size as the original system. Therefore, the old system was simply removed from the roof, and the new IADR was easily installed on the original roof curb using a custom curb adapter.

Because of the increased system operating efficiency, the existing electrical and gas service could be used for the new IADR, despite the significant increase in net cooling and dehumidification capacity.

The integrated DDC system (Figure 4) communicates with and controls both the conditions and the airflow delivered to the VAV boxes. It optimizes the amount of energy used by the IADR to reach the delivered temperature and dewpoint required by the space. It also provides real-time monitoring and trending of more than 70 performance parameters and psychrometric conditions associated with the system. Data have been collected for more than a year, including a summer shutdown during which the system controlled space humidity using a reduced outdoor airflow volume (an important benefit to school facilities).
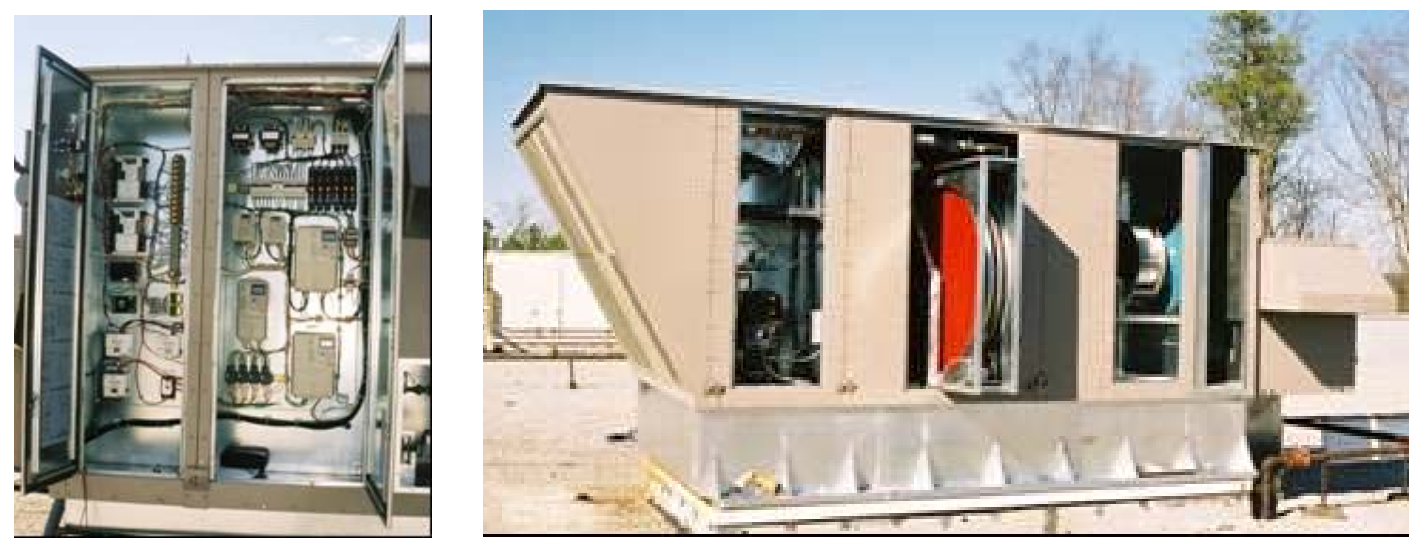

Figure 4. The DDC/data acquisition compartment, desiccant wheel and service access of the IADR unit. 


\subsection{Benefits Realized by Applying the IADR as a VAV System}

The Atlanta school realized a number of benefits as a result of the IADR retrofit. (Some of these will be covered later in more detail.) Briefly summarized, the following are key benefits of the IADR:

- It offered the lowest possible first cost for renovating the existing VAV system so that it would function as desired. Based on a detailed engineering analysis presented later, it would also appear that this approach will provide the lowest first cost for new construction as well.

- Operating costs are extremely low as a result of several factors:

- Delivery of low-dewpoint air using moderate leaving coil temperatures made possible by the active desiccant wheel.

- Extremely high cooling system energy-efficiency ratios (EERs) associated with the advanced refrigeration design and variable-speed compressor.

- Low fan energy consumption made possible by true VAV operation.

- Higher space thermostat settings as a result of lower space humidity conditions.

- Integrated total energy recovery to precondition the outdoor ventilation air volume.

- The delivery of supply air conditioned to a moderate temperature $\left(60^{\circ} \mathrm{F}\right)$ and a low dewpoint $\left(50^{\circ} \mathrm{F}\right)$ allowed the space humidity to be controlled as desired without the costly overcooling followed by reheat that is common in conventional VAV systems.

- The option to use the dehumidification section only and avoid the use of refrigeration during cool, humid days.

- The ability to use natural gas for winter heating delivered by the unit rather than electric reheat applied at the individual VAV boxes.

- The ability to monitor outdoor air temperature and humidity to allow for an effective economizer application, when appropriate, without losing humidity control within the space.

- IAQ is greatly improved because the desired ventilation airflow is delivered continuously whatever the amount of supply air delivered. The system often operates as a near-100\% outdoor air system. IAQ complaints, once frequent, are now eliminated in the section of the school served by the new system.

- The improved humidity control allowed all of the commercial dehumidifiers to be removed from the area of the school facility served by the IADR system.

- The improved humidity control improved comfort and has caused occupants to raise the thermostat settings within the space, significantly reducing the cost of operation.

- Teachers now have excellent control over their individual room conditions without the noise, condensate management problems, and fluctuating supply air temperatures associated with heat pump or fan coil designs.

- Teachers are comfortable when they are the only occupants and are not overcooled.

- The school district has the ability to easily monitor the conditions in each individual classroom, the airflow delivered to each classroom, the humidity conditions within the school, the energy consumed by the IADR system, and a number of other performance parameters that allow for building observation and remote system trouble-shooting.

- Filters are easily maintained in one central location as opposed to filters in each classroom. Maintenance is greatly reduced, and the higher static pressure capabilities of the IADR system allow for the use of higher-efficiency filtration, which results in a cleaner space. All these factors reduce maintenance costs.

- The IADR has an energy-efficient unoccupied mode that is highly beneficial for schools because although a school is unoccupied much of the time, it is important to monitor and maintain acceptable humidity levels at all times. In this mode, the humidity is controlled at an elevated space temperature to avoid microbial problems at a low operating cost. 
- The soft start of the variable-speed compressors significantly increases the life expectancy of the compressors. The inverter-driven direct-drive supply fan eliminates belt maintenance.

\subsection{Addition of the Energy Recovery Module}

Figure 5 shows how the total energy recovery module can be effectively integrated along with the IADR system without the need for additional roof penetrations, ductwork, or electrical connections. Including this module greatly reduces the installed cooling capacity required by the IADR. For this project, the energy recovery module eliminated approximately 10 tons of cooling capacity. During the heating season, the energy recovered allows the building to be self-heating most of the time.

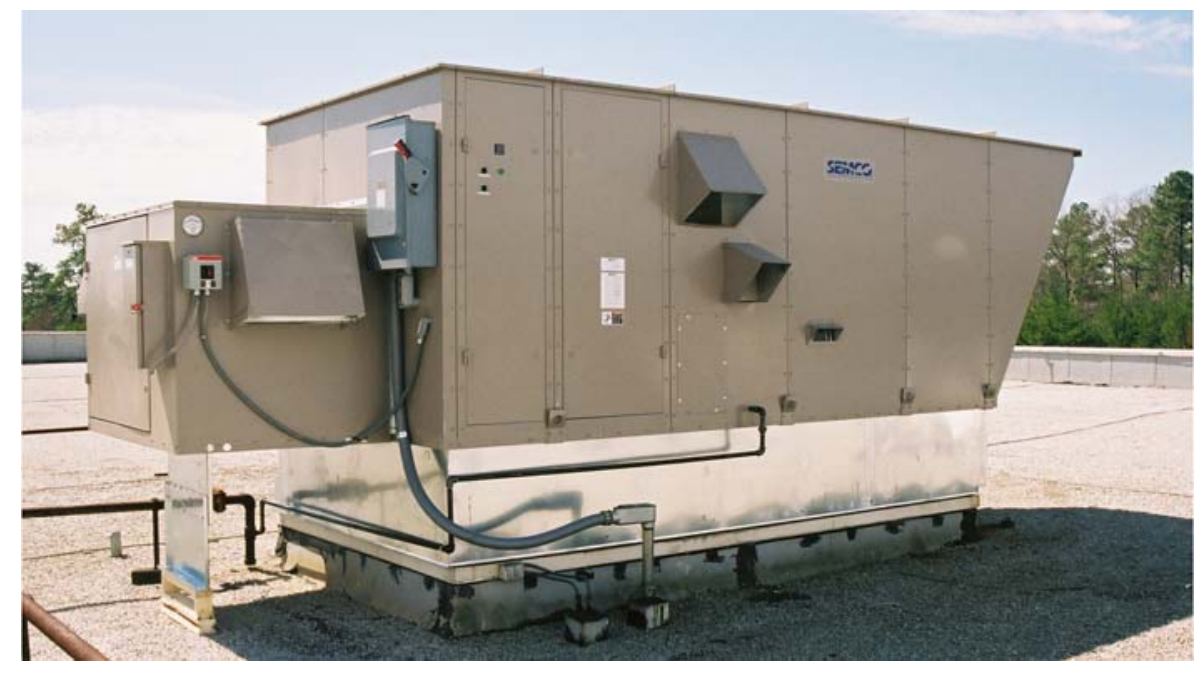

Figure 5. The regeneration side of the IADR and integrated recovery module.

The energy recovery module incorporates an airflow measuring device that measures the amount of outdoor air delivered to the school facility. ASHRAE 62 recommends the measurement and routine inspection of the amount of outdoor air delivered to a facility; this device greatly simplifies this process for the school. This investigation provided documentation of a constant flow of outdoor air despite the variation in the supply air volume. 


\section{PERFORMANCE DOCUMENTED FOR THE IADR VAV SYSTEM}

\subsection{Temperature and Humidity Control Realized}

One of the most obvious and dramatic improvements in system performance following the installation of the IADR system was the level of temperature and humidity control and the ability to control them independently (even during unoccupied periods).

Figure 6 shows a typical data set for temperature and relative humidity trended for the return air stream entering the IADR system in a typical 24-hour period (cooling season). The return air temperature and relative humidity were very consistent despite wide fluctuations in indoor and outdoor conditions. A constant outdoor air volume of approximately $3000 \mathrm{cfm}$ was delivered to the space served by the IADR system.

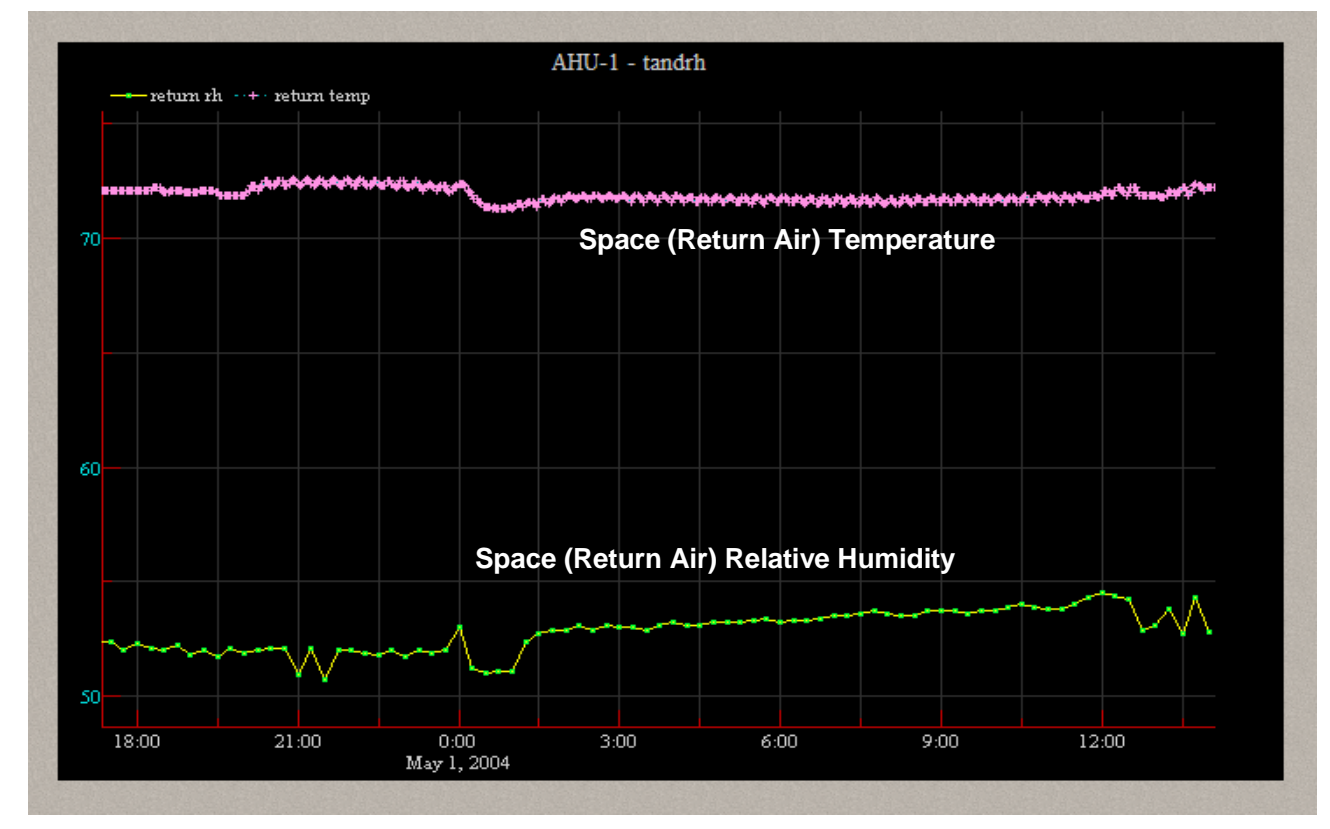

Figure 6. Sample of the return air plenum temperature and humidity data provided by the DDC system.

Sections of the school served by the conventional equipment and operated without any outdoor air experienced the traditional saw-tooth swing associated with cycling compressors with regard to temperature (Figure 7). Humidity was uncontrolled, despite the assistance of numerous commercial dehumidifiers located in many classroom areas.

Figure 8 provides a better example of the effective space humidity control provided by the IADR because the control parameter used is dewpoint and not relative humidity (set to a dewpoint value of $56^{\circ} \mathrm{F}$, corresponding to approximately 65 grains or $50 \%$ relative humidity at $75^{\circ} \mathrm{F}$ ). The data confirm ideal humidity control, which would have been almost impossible to obtain with conventional packaged systems.

This statement is further supported by the supply air dewpoint needed to maintain the desired return air dewpoint. Note in Figure 8 that to maintain the desired $56^{\circ} \mathrm{F}$ dewpoint, the supply air needed to be dehumidified to a $43-48^{\circ} \mathrm{F}$ dewpoint. These conditions are problematic even for specialized packaged HVAC equipment (Gatley 2000; Harriman, Brendrett, and Kittler 2001). They require the dehumidification capability unique to active desiccant systems. 
Typical Space Relative Humidity Before and After Hybrid Rooftop System Retrofit

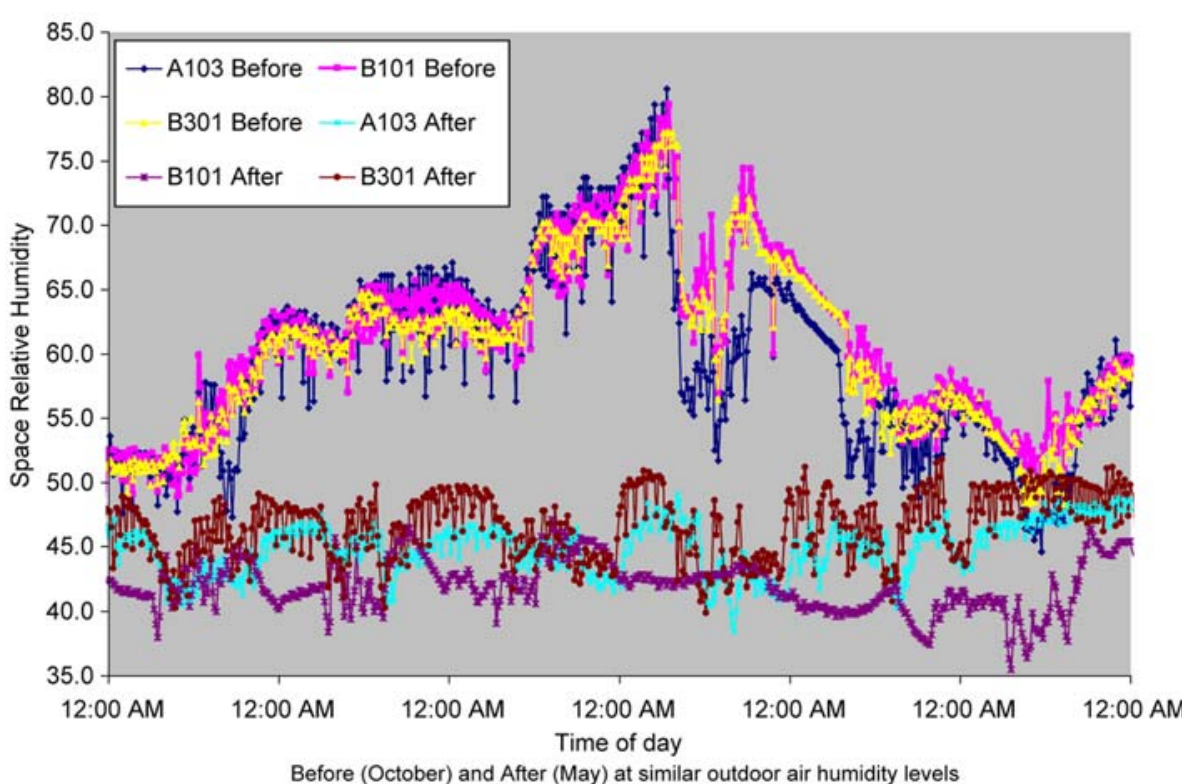

Figure 7. Sample of classroom humidity data collected by Georgia Tech Research Institute before and after the IADR retrofit.

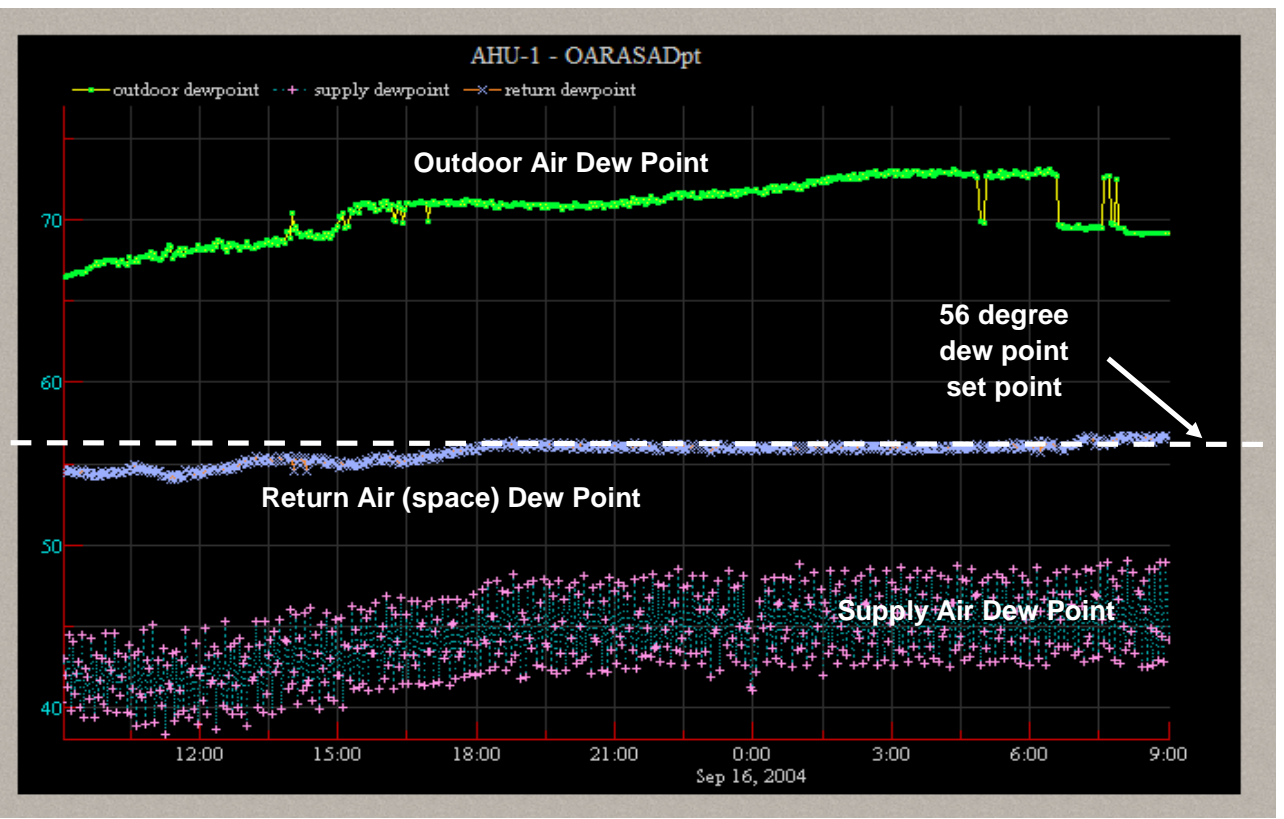

Figure 8. Sample of the return air humidity control and supply dewpoint delivered by the IADR.

The IADR modulates a variable-speed compressor in conjunction with a bypass damper and active desiccant wheel to provide the desired dewpoint needed to meet the space conditions while simultaneously delivering the moderate supply air temperature needed to match the space sensible load (Fischer and Sand 2004). 
In addition to the instrumentation installed as part of the IADR DDC package, additional instrumentation was placed in the individual classroom areas as part of an IAQ investigation conducted by GTRI. Figure 7 summarizes the relative humidity measured in several classrooms before and after the system retrofit. The samples were collected under similar outdoor air temperature and humidity conditions. As shown, the conventional packaged system previously used (that was delivering no outdoor air and was augmented by commercial dehumidifiers installed in the rooms) could not control the space humidity. The resulting humidity often exceeded the $60 \%$ guideline recommended by ASHRAE and was observed to be as high as $80 \%$ at times.

Conversely, after the installation of the IADR, the same classrooms were controlled at or below $50 \%$ relative humidity consistently (Figure 7). The stand-alone dehumidifiers were no longer needed and were removed from the classrooms served by the IADR system.

\subsection{Higher Thermostat Settings Associated with Improved Humidity Control}

As part of a larger DOE-co-sponsored school IAQ investigation, summarized in Fischer and Bayer 2003, it was reported that the schools investigated with effective humidity control were operated at higher average thermostat settings, which were chosen by the occupants (teachers and students).

Figure 9 shows the Atlanta school realized similar benefits once the IADR system was installed. Following the installation of the IADR, the average thermostat setting for the three classrooms trended by GTRI was $2.4^{\circ} \mathrm{F}$ higher than it was before the system retrofit $\left(72.8^{\circ} \mathrm{F}\right.$ vs $\left.70.4^{\circ} \mathrm{F}\right)$. At the same time, occupants reported that the comfort level had improved considerably (the rooms were comfortable rather than cold and clammy).

Significant energy savings have been realized by this $2.4^{\circ} \mathrm{F}$ change in the space thermostat setting. The energy savings associated with this higher thermostat setpoint are discussed in more detail in Section 3.3.4.

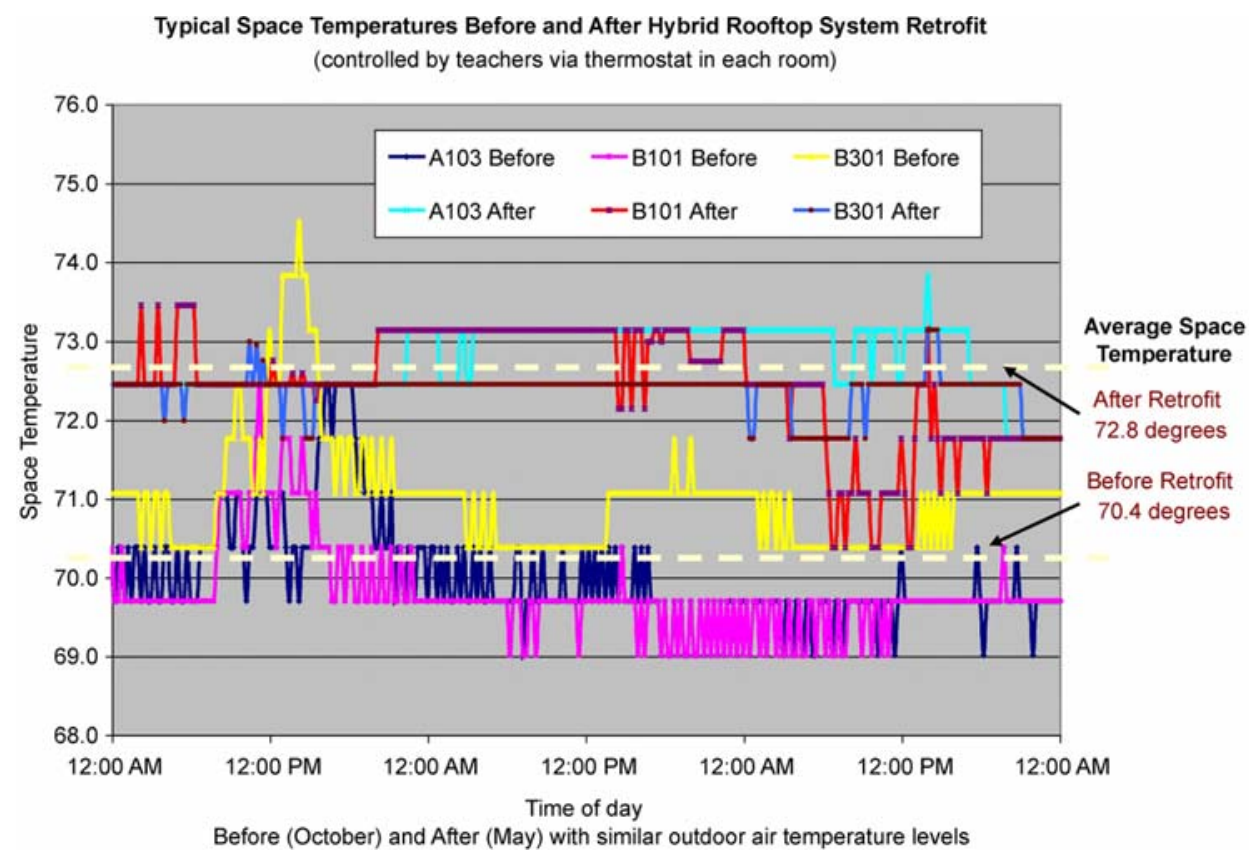

Figure 9. Sample of classroom temperature data collected by the Georgia Tech Research Institute before and after the IADR retrofit. 


\subsection{Energy Efficiency Realized with the IADR Hybrid System Integration}

In addition to the improvement in space comfort conditions (both temperature and humidity) and building IAQ, significant energy savings have been realized compared with the energy consumption associated with more conventional technologies selected to deliver like conditions. These energy savings are a result of several design features integrated into the IADR hybrid. Some of the more important enhancements are as follows.

\subsubsection{Reduction in Tons of Cooling Capacity Required}

One of the important innovations associated with the IADR hybrid system is the integration of the active desiccant wheel to effectively provide a large portion of the dehumidification or latent capacity (see Bayer, Crowe, and Fischer 2000 for details). Low-dewpoint air from the active desiccant wheel mixes with the portion of the supply air stream processed by the cooling coil and bypassed around the active desiccant wheel to deliver supply air at a desired dewpoint and moderate leaving coil temperature, using higher refrigerant suction temperatures. Conventional cooling-only approaches would have to cool the air to a much lower temperature, relying on much lower refrigeration suction temperatures and thereby less efficient operation to reach an equivalent humidity condition. This also requires far more installed cooling capacity and condenser fan energy.

For example, the installed cooling capacity required by the IADR for this demonstration project was 25 tons. With this capacity, supply air having a dewpoint of $46.7^{\circ} \mathrm{F}$ can be delivered at design dry bulb conditions. The air temperature leaving the cooling coil is approximately $53^{\circ} \mathrm{F}$.

A conventional system employed without recovery would have to allocate approximately 50 tons of cooling capacity to create the $47^{\circ} \mathrm{F}$ air required to reach the desired supply air humidity level. Approximately 40 tons would be required if total energy recovery were used . The much lower suction temperature required by the conventional approach significantly reduces operating cooling efficiency (EER, Btu $\bullet \mathrm{h} / \mathrm{W})$.

Table 2 summarizes a side-by-side comparison between the IADR used and the conventional overcooling system that would be required to deliver the desired sensible and latent capacity. It includes a comparison with a conventional rooftop unit sized for the total load (sensible and latent) without regard for the resulting space humidity levels. As shown, the relative humidity associated with the conventional rooftop unit approach is projected to be approximately $80 \%$. This unacceptable level explains, in part, why the outdoor air dampers are often closed in these systems in an attempt to reach an acceptable comfort level, as was the case with the original system replaced by the IADR.

\subsubsection{Higher Cooling Side Efficiency Due to Variable-Speed Compressor}

One of the most significant energy savings enhancements of the IADR hybrid unit is the advanced refrigeration design and controls, including the integration of a variable-speed compressor. In addition to providing ideal capacity control, it is more energy-efficient than a conventional highefficiency packaged system. The energy efficiency difference becomes more pronounced at off-peak conditions. The reasons for this efficiency increase are many, including lower refrigerant system pressures, lower condensing temperatures, increased sub-cooling, optimum use of oversized heat exchanger coils, and most important, avoiding the use of hot gas bypass capacity control.

A detailed explanation goes beyond the scope of this report, but the potential for significant increases in cooling efficiency has been observed in this project as well as at the ORNL Cooling, Heating, and Power Integration Laboratory, where a smaller version of the active desiccant hybrid system has been installed and tested (Petrov et al. 2005). Table 3 summarizes testing completed at ORNL to determine how the unit's cooling EER (no desiccant wheel involved) compares with that listed for conventional rooftop units. 
Table 2. Comparison of cooling capacity required for the IADR and for a customized packaged unit without recovery. A conventional packaged unit cannot meet the load even at 30 tons (middle column)

\begin{tabular}{|c|c|c|c|}
\hline & IADR & Packaged System & Packaged System with Reheat \\
\hline $\begin{array}{c}\text { Sensible load required } \\
\text { Latent load required } \\
\text { SHR }\end{array}$ & $\begin{array}{c}143,600 \mathrm{Btu} / \mathrm{h} \\
187,078 \mathrm{Btu} / \mathrm{h} \\
0.43\end{array}$ & $\begin{array}{c}143,600 \mathrm{Btu} / \mathrm{h} \\
187,078 \mathrm{Btu} / \mathrm{h} \\
0.43\end{array}$ & $\begin{array}{c}143,600 \mathrm{Btu} / \mathrm{h} \\
187,078 \mathrm{Btu} / \mathrm{h} \\
0.43\end{array}$ \\
\hline $\begin{array}{l}\text { Sensible load delivered } \\
\text { Latent load delivered } \\
\text { SHR }\end{array}$ & $\begin{array}{c}141,814 \mathrm{Btu} / \mathrm{h} \\
187,078 \mathrm{Btu} / \mathrm{h} \\
0.43\end{array}$ & $\begin{array}{c}278,640 \mathrm{Btu} / \mathrm{h} \\
96,198 \mathrm{Btu} / \mathrm{h} \\
0.74\end{array}$ & $\begin{array}{c}141,814 \mathrm{Btu} / \mathrm{h} \\
187,078 \mathrm{Btu} / \mathrm{h} \\
0.43\end{array}$ \\
\hline $\begin{array}{l}\text { Space humidty peak load } \\
\text { Space humidity part load }\end{array}$ & $\begin{array}{l}\mathbf{5 0 \%} \\
\mathbf{5 0 \%}\end{array}$ & $\begin{array}{l}80 \% \\
79 \%\end{array}$ & $\begin{array}{l}\mathbf{5 0 \%} \\
\mathbf{5 0 \%}\end{array}$ \\
\hline $\begin{array}{l}\text { Space temperature needed } \\
\text { to reach occupant comfort }\end{array}$ & $75.9^{\circ} \mathbf{F}$ & $\begin{array}{l}70.9^{\circ} \mathrm{F} \\
71.1^{\circ} \mathrm{F}\end{array}$ & $75.9^{\circ} \mathbf{F}$ \\
\hline $\begin{array}{c}\text { Tons needed for latent load } \\
\text { Reheat energy required } \\
\text { Regeneration energy }\end{array}$ & $\begin{array}{c}23.8 \text { tons } \\
\text { 0 Btu/h } \\
134,851 \mathrm{Btu} / \mathrm{h}\end{array}$ & $\begin{array}{l}\text { 30.0 tons } \\
\text { (Tons typically installed) } \\
\text { Humidity Conditions Not Met } \\
\text { with this standard selection! }\end{array}$ & $\begin{array}{l}\text { 48.9 tons } \\
133,428 \mathrm{Btu} / \mathrm{h} \\
\text { 0 Btu/h }\end{array}$ \\
\hline
\end{tabular}

Table 3. Comparison of cooling efficiency (EER) of the IADR and a conventional rooftop unit at part-load conditions (variable compressor speeds) based on field and laboratory test data

EER Data Based on Field Testing

\begin{tabular}{|cccc|c|c|}
\hline \multicolumn{3}{|c|}{ Field Measured for IADR Hybrid } & \multicolumn{2}{c|}{ Conventional RTU Literature * } & EER Increase \\
\hline hz & tons & kw & EER & EER & Percent \\
\hline 60 & 13.0 & 11.5 & 13.6 & $\mathbf{1 1 . 3}$ & $20 \%$ \\
50 & 12.3 & 9.3 & 15.9 & $\mathbf{1 1 . 0}$ & $\mathbf{4 4 \%}$ \\
40 & 10.8 & 7.2 & 18.0 & $\mathbf{1 0 . 0}$ & $\mathbf{1 1 4 \%}$ \\
30 & 9.0 & 5.6 & 19.3 & $\mathbf{9 . 0}$ & $145 \%$ \\
20 & 6.2 & 3.8 & 19.6 & $\mathbf{8 . 0}$ & \\
\hline
\end{tabular}

- "Packaged Heat Pumps," Voyager ${ }^{\mathrm{TM}}$, PKGP-PRC001-EN, October 2003, Trane.

- "Packaged Heat Pumps," Precedent ${ }^{\mathrm{TM}}$, PKGP-PRC003-EN, February 2004, Trane.

As the system was operated at different levels of part-load capacity (reduced compressor speed), the level of energy vs. cooling output (EER) increased. The full-capacity EER was determined to be 13.6, $20 \%$ higher than that of a typical rooftop unit. As the compressor speed was reduced, however, the measured EER increased significantly, reaching almost 20 at the minimum compressor speed tested.

Note that conventional rooftop systems can accommodate part-load conditions only by either cycling compressors or using hot gas bypass. The latter approach is far less efficient but is often used if cycling of the delivered temperature or humidity is not desired or if a low supply air dewpoint is needed and coil frosting is a concern. The integration of the variable-speed compressor and airmoving fans resolves all of these concerns while significantly increasing energy efficiency.

\subsubsection{Elimination of VAV Box Reheating Requirements}

Reheating is used by most traditional VAV systems for two reasons: heating season space conditioning and cooling season humidity control (which is not permitted by ASHARE 90.1). 
Nonetheless, it is common to see reheating used, especially in schools, during the cooling season because the leaving coil temperature needed to control humidity (approximately $52^{\circ} \mathrm{F}$ ) will often overcool a classroom space when the minimum box setting is correctly set to meet the ventilation requirements. Since reheating at the VAV box is often done with electric resistance heat, it results in a system that is inefficient and expensive to operate.

There is no reheating in the duct or individual VAV boxes installed at the pilot site served by the IADR system. All winter season space heating is provided by the gas-fired desiccant regeneration burner located within the IADR unit. Increasing the rotational speed of the active desiccant wheel and reducing the amount of air bypassed around the wheel provides a modulating indirect gas-fired heat exchanger.

The individual VAV boxes are continuously monitored and adjusted. Once heating is required in classroom areas, the supply air temperature is gradually increased until the heating load is met. The variable airflow volume capability of the system combined with the modulating gas burner delivers air at the temperature needed to maintain the setpoint.

During the cooling season, no reheating is required because the combination of the cooling coil and the active desiccant wheel provide space humidity control. Since the IADR can independently deliver the temperature and humidity conditions required by the space, a moderate supply air temperature, typically in the range of $60^{\circ} \mathrm{F}$, is delivered. At this temperature, the space will not feel drafty and will not overcool, even at low occupancy. Since a low dewpoint, typically in the range of $50^{\circ} \mathrm{F}$, can be delivered at the $60^{\circ} \mathrm{F}$ supply air temperature, space humidity control is easily maintained by measuring the return air humidity level and adjusting the supply air dewpoint accordingly. This is done by modulating the regeneration heat delivered to the active desiccant wheel.

\subsubsection{Reduced Energy Use Associated with Higher Space Temperature Setpoints}

After the IADR retrofit improved humidity levels in the school, occupants raised individual classroom thermostat setpoints from an average of $70.4^{\circ} \mathrm{F}$ to an average of $72.8^{\circ} \mathrm{F}$. As part of an earlier ORNL project (Fischer and Sand 2004), the University of Chicago conducted DOE 2.1 modeling to relate the impact of the space thermostat setting on cooling season energy consumption. Figure 10 summarizes this modeling specifically for school facilities. It confirms that the $2.4^{\circ}$ higher average thermostat setting that followed installation of the IADR at the Atlanta school is projected to reduce cooling season energy consumption by approximately $10 \%$. The room thermostats allow for only a $2^{\circ}$ change from the predetermined midrange set point currently set at $71^{\circ}$.

During the next cooling season, it will be recommended that this midrange set point be increased to $73^{\circ}$. Based on the findings presented in Fischer and Bayer 2003, the average thermostat setting chosen by occupants is then expected to increase to approximately 74 to $75^{\circ}$.

\subsubsection{Integrated Total Energy Recovery Module Impact}

Schools almost always have an exhaust air path from the building so that outdoor ventilation air can be delivered. In such cases, use of a total energy recovery (enthalpy) wheel should be considered because it can produce a sizeable reduction in both operating costs and cooling/heating capacity.

For the Atlanta school, the integrated total energy recovery module reduced the peak cooling load on the cooling coil in the IADR by approximately 10 tons. During the heating season, approximately $165,000 \mathrm{Btu} /$ hour of heating and humidification energy are recovered by the module. Energy savings attributable to the recovery module were projected to be approximately $\$ 1900$ annually. Figure 11 shows the typical cooling design performance associated with the total energy recovery module integrated into the IADR system. 
Typical School Facility:

(165,000 SqFt., 32\% Outdoor Air)

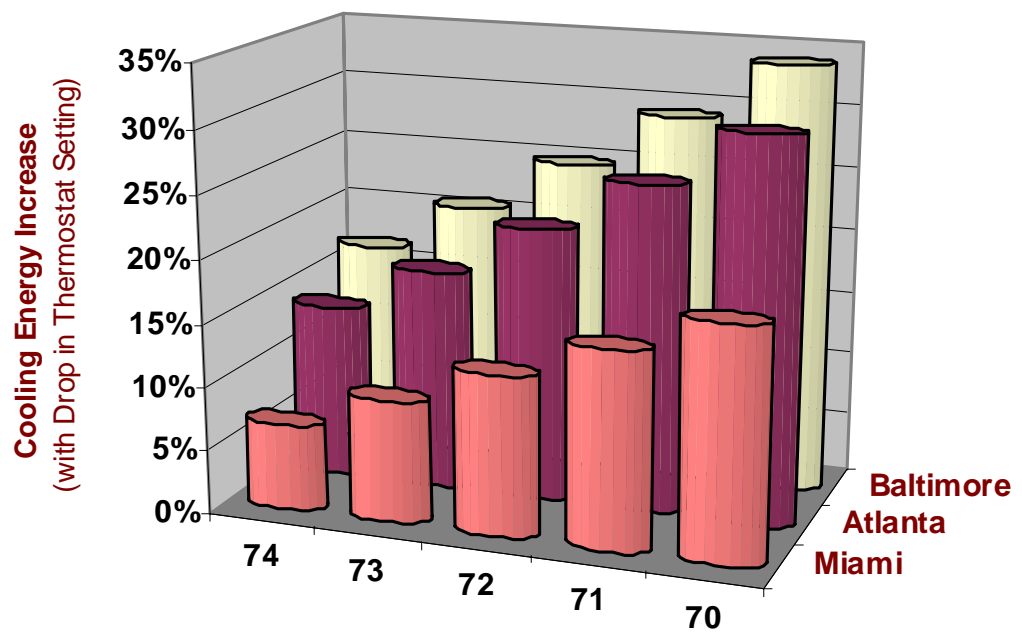

Thermostat Setting

(Degrees F)

Figure 10. Summary of DOE 2.1 modeling to estimate the increase in cooling energy cost as the thermostat setting is incrementally reduced from $75^{\circ} \mathrm{F}$.

\section{Project: Atlanta School with IADR}

Location: Atlanta

Model: FV-3000

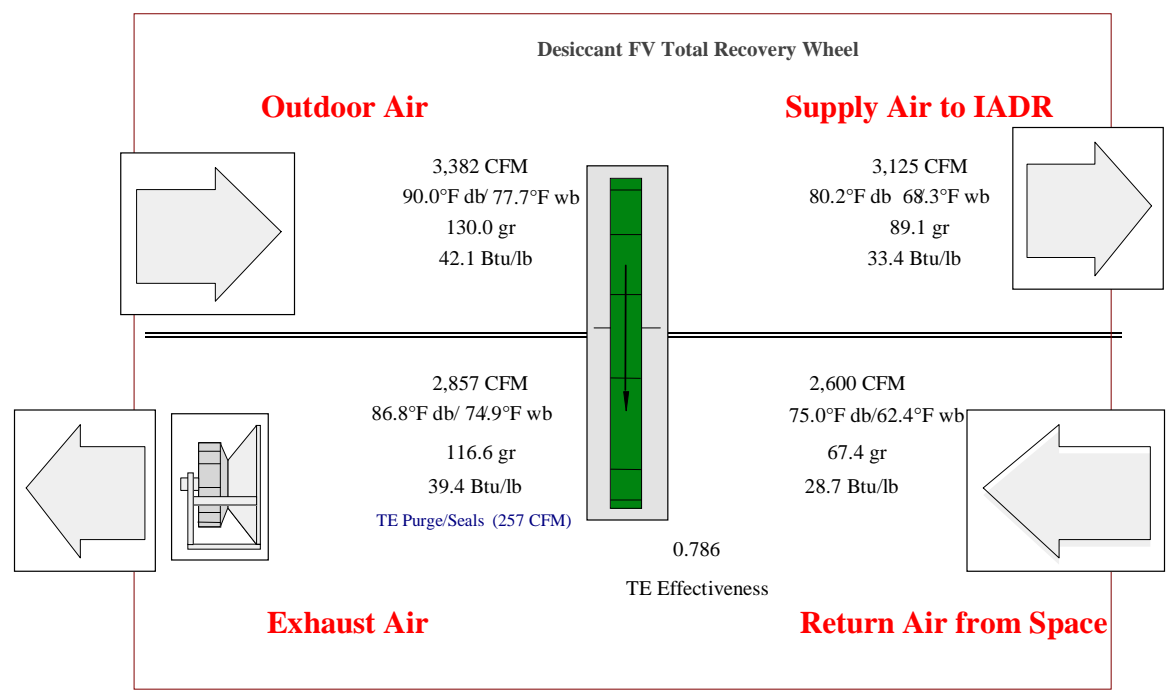

Figure 11. Sample performance of the total energy recovery module integrated into the IADR system for the school pilot project. Cooling mode is shown; however, heat recovery is equally important. 


\subsubsection{Fan Energy Savings}

The school HVAC system that was replaced by the IADR was promoted as a VAV system, yet the airflow through the air-handling unit was maintained at approximately $9000 \mathrm{cfm}$ independent of the amount of airflow delivered to the VAV boxes. This was done to ensure a constant airflow across the cooling coil, which was required to avoid a number of operational problems. Bypass dampers installed in the main ductwork would open to allow air to be recirculated between the supply and return connections to the air-handling unit.

In sharp contrast, the IADR system is operated much like a chilled water system, with the airflow across the cooling coil varying in response to changing space cooling or heating loads. Based on data collected over a 1-year period, the average supply air volume delivered by the IADR system during occupied hours was $5200 \mathrm{cfm}$, or $58 \%$ of its design full-flow capacity. Large energy savings are recognized as a result, since both the flow and the static pressure across the fan drop as the need for heating and cooling capacity is reduced. For this project, the annual energy cost savings associated with reduced fan horsepower has been estimated to be $\$ 952$.

\subsection{Heating Mode Operation}

In heating mode, the energy recovery module has a significant positive impact on both energy efficiency and the stability of overall system operation. For example, when the outdoor air is $20^{\circ} \mathrm{F}$, the outdoor air is preheated to approximately $55^{\circ} \mathrm{F}$ in addition to being humidified. This preconditioned outdoor air is introduced into the return air stream, resulting in a mixed air temperature of approximately $63^{\circ} \mathrm{F}$. The space setpoint temperature can be maintained with a supply air condition of approximately $80^{\circ} \mathrm{F}$ on a design day. As a result of heat recovery from the building exhaust, heating season energy use was low.

All winter season space heating is provided by the gas-fired desiccant regeneration burner located within the IADR unit, which serves the dual purpose of regenerating the desiccant wheel and heating the conditioned space. Modulating indirect gas heating is provided by increasing the rotational speed of the active desiccant wheel and reducing the amount of air bypassed around it. To effect this change, the rotation rate of the desiccant wheel was increased from $12 \mathrm{rph}$ in dehumidification mode to $300 \mathrm{rph}$ in heating mode, and the amount of air bypassing the desiccant wheel was decreased from $80 \%$ in summer to $50 \%$ in winter.

Space heating is seldom needed during occupied periods because the sensible loads associated with the lighting and the building occupants tend to offset the heat loss through the envelope, and the integrated recovery module buffers the facility from cold outdoor air that would challenge wellventilated spaces served by conventional systems. During unoccupied periods, the outdoor air delivered to the space is usually eliminated, and the only heating load is the building envelope losses.

Figure 12 shows how the IADR accommodates different outdoor and indoor load conditions, reflecting both cooling and heating operation. In this example, the outdoor air was provided continuously during both occupied and unoccupied periods. As shown, between approximately 11:00 p.m. and 8:00 a.m., the building required modest heating as the building internal sensible load was removed and the outdoor air temperature dropped to $58^{\circ} \mathrm{F}$. The system responded by delivering air at approximately $78^{\circ} \mathrm{F}$, as needed, to maintain desired space temperatures in the individual classrooms (space temperature shown is the aggregate mixed return plenum air temperature).

The 240,000 Btu/hour maximum burner capacity installed with this unit was adequate to heat the space served by the IADR system despite days with ambient temperatures as low as $15^{\circ} \mathrm{F}$ during the winter. 


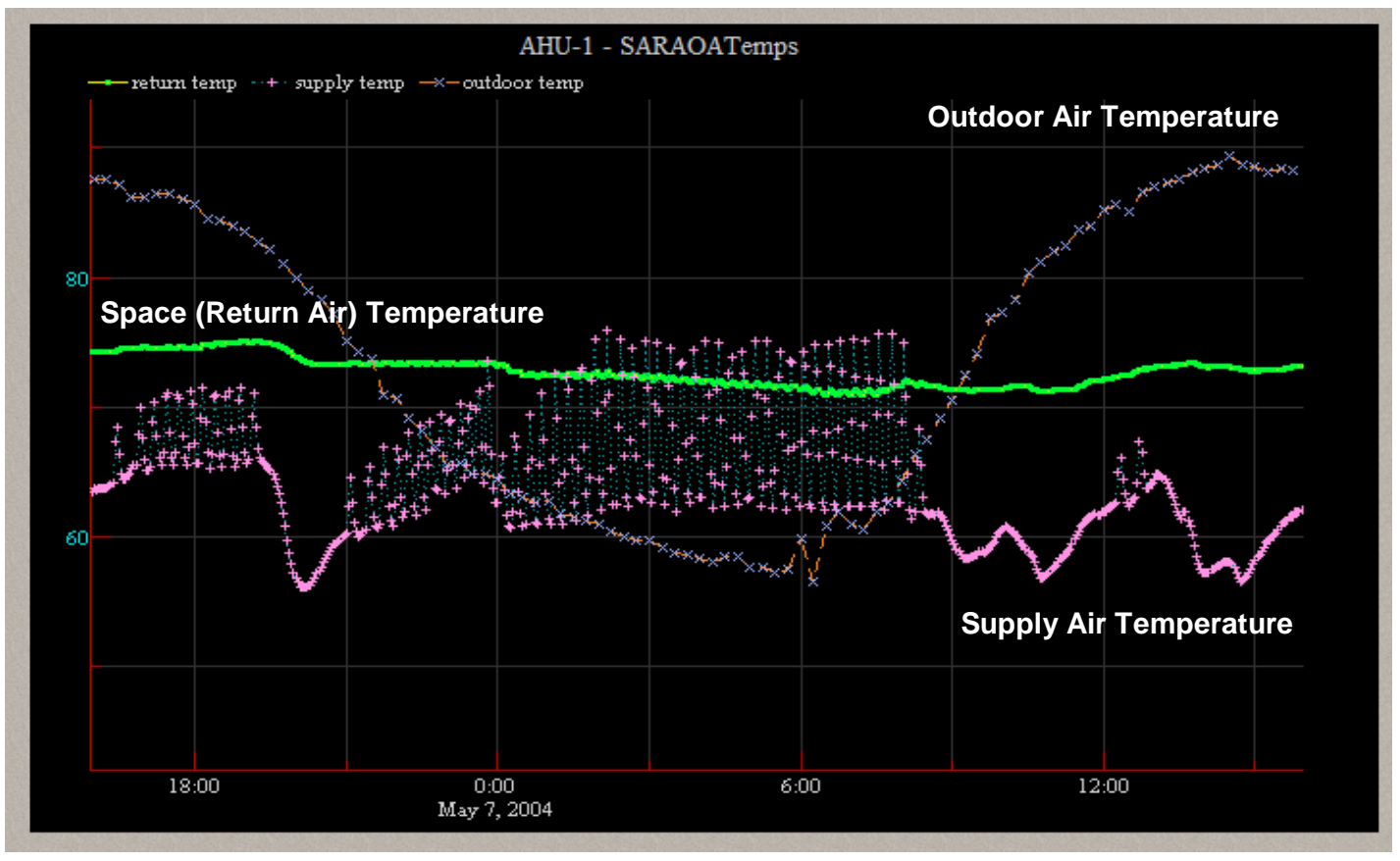

Figure 12. Sample performance of the IADR as it responds to the control system's request to accommodate both heating and cooling conditions over one 24 hour period. 


\section{INDOOR AIR QUALITY INVESTIGATION-GEORGIA TECH RESEARCH INSTITUTE}

For years, this Georgia school had experienced serious humidity and IAQ problems that had resulted in frequent occupant complaints and microbial (mold) remediation. The outdoor air louvers of the original HVAC units had been closed in an attempt to improve humidity control within the space. As a result, the only ventilation was a result of infiltration.

In addition to improving space temperature and humidity control, which could be easily measured and trended, a second objective of this research pilot was to document any improvement in IAQ and occupant satisfaction that resulted from the IADR retrofit.

To obtain these data, GTRI and Georgia State University were funded to investigate IAQ. This work was to build upon the sizeable database that resulted from previous work summarized in various technical publications (e.g., Fischer and Bayer 2003; Bayer, Crowe, and Fischer 2000; Bayer et al. 2002; Fischer 1996).

\section{1 $\mathrm{CO}_{2}$ Data Measured before and after the IADR Retrofit}

To establish a surrogate for the effectiveness of ventilation provided to the individual classrooms before and after the IADR retrofit, $\mathrm{CO}_{2}$ data loggers were installed in select classrooms. Figure 13 provides a sample typical of the data collected. As can be seen, before the retrofit, the peak $\mathrm{CO}_{2}$ levels routinely peaked above $1500 \mathrm{ppm}$. Following the retrofit, the peak $\mathrm{CO}_{2}$ level was reduced to approximately $1200 \mathrm{ppm}$.

Note that the amount of outdoor air delivered by the IADR was determined for this VAV application by using the ASHRAE Standard 62 multiple-space spreadsheet tool (previously known as the $\mathrm{Z}$ factor). In this procedure, the outdoor air percentage delivered to a given space is reduced based on credits for other "over-ventilated" spaces. As a result, the amount of ventilation is often less than

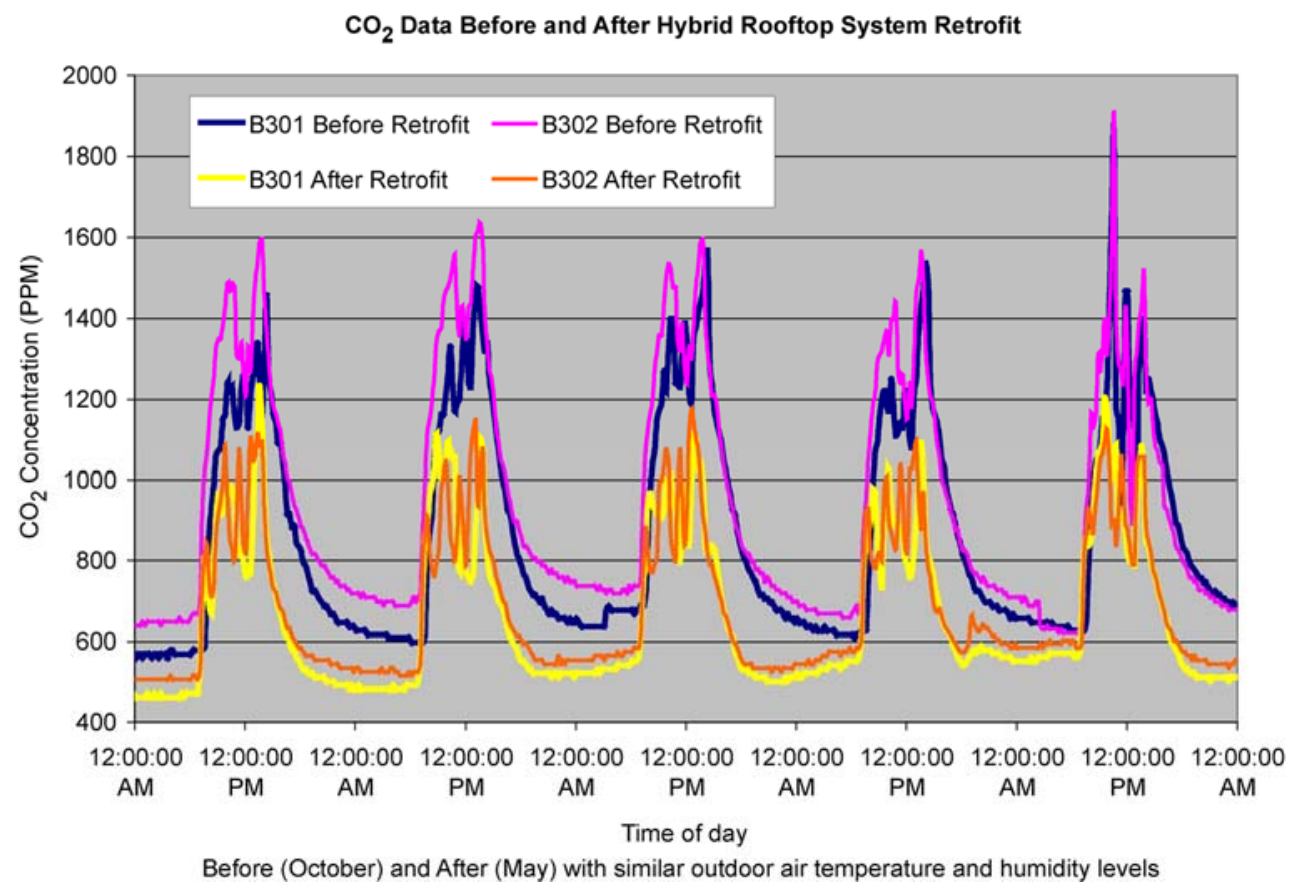

Figure 13. Carbon dioxide $\left(\mathrm{CO}_{2}\right)$ data collected by Georgia Tech Research Institute for classrooms before and after the IADR retrofit. 
the $15 \mathrm{cfm}$ per person recommended by the ventilation approach of Standard 62, explaining why the $\mathrm{CO}_{2}$ level exceeds the 1000-ppm guideline commonly referred to in IAQ investigations (ASHRAE 2004).

All teachers interviewed who were located within the portion of the school building served by the IADR retrofit reported a dramatic improvement in the quality of the indoor air.

\subsection{Formaldehyde Data}

As in previous IAQ investigations conducted by GTRI, total volatile organic compounds and various other important indoor contaminants were measured. As expected, the levels of these contaminants were significantly reduced as a result of the increased ventilation provided by the IADR retrofit.

The formaldehyde data presented in Figure 14 are perhaps the most important, since formaldehyde has recently been classified as a suspected carcinogen (ACGIH 1999, NIOSH 2002). As a result, the NIOSH recommended exposure limit for indoor working environments has been reduced to $.016 \mathrm{ppm}\left(20 \mu \mathrm{g} / \mathrm{m}^{3}\right)$. The formaldehyde data shown in Figure 14 confirm that at least 15 $\mathrm{cfm}$ of ventilation air per person (as recommended by ASHRAE Standard 62) was required to maintain formaldehyde levels below the NIOSH guideline limits. This agrees well with one of the important findings resulting from the previous investigation of large schools (Fischer and Bayer 2003).

Table C-2 of ASHRAE 62 has not yet reflected these current scientific data for formaldehyde. Once considered, they should provide strong support for maintaining, if not increasing, the ventilation rates currently referenced by ASHRAE 62 (ASHRAE 2004).

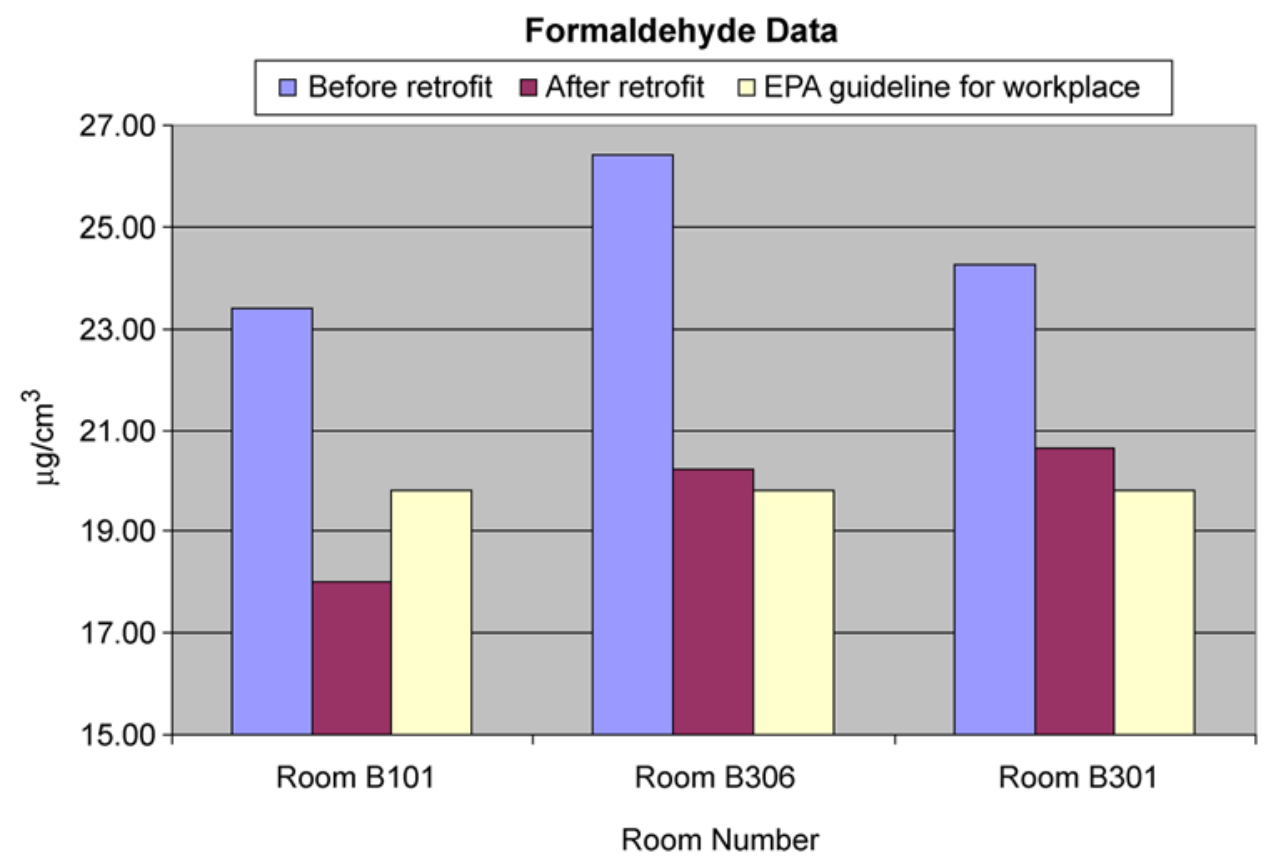

Figure 14. Formaldehyde data collected by Georgia Tech Research Institute for classrooms before and after the IADR retrofit.

Since the $20 \mu \mathrm{g} / \mathrm{m}^{3}$ NIOSH guideline is for formaldehyde in the industrial workplace, the level within a school facility should arguably be maintained at a substantially lower level, providing support for more than $15 \mathrm{cfm} /$ person. 


\subsection{Microbial Investigation}

For years prior to the retrofit, it was not uncommon for the classrooms in this school to be treated with bleach and other chemicals to remove mold growing within the carpet and on furnishings. This problem prompted the installation of commercial dehumidifiers in each classroom (in addition to closing off all outdoor air) to reduce space humidity. As expected, this modification helped reduce the microbial problems observed.

With the addition of the IADR system, the dehumidifiers were removed from the classroom spaces for the first time in years. Testing completed after the IADR system had operated at the school for a cooling season detected no significant microbial activity within the spaces it served. The odors associated with the microbial activity, frequently reported before the retrofit, were eliminated and have not returned. 


\section{CUSTOMER FEEDBACK REGARDING THE EFFECTIVENESS OF THE PILOT INSTALLATION}

Verbal interviews were conducted with the school principal as well as the teachers occupying the classrooms and workrooms served by the IADR system. In all cases, it was reported that the improvement in both comfort and indoor air quality was significant. After more than a year of operation, no IAQ or comfort problems have been reported.

The success of the pilot project actually created a different issue in that only one section of the school facility has been fully improved. The remaining classrooms are still served by conventional systems and commercial dehumidifiers. Until funding is found to replace the remaining systems, there will be a wide variation in the conditions within the same building. Fortunately, the ventilation air and dehumidification provided by the IADR has also made some improvement to the other areas served by conventional systems. The very low dewpoints called for by the control system confirm that spaces other than those served by the IADR are being dehumidified.

A letter attached as an appendix to this report was provided by the school district where the system has been installed. The letter confirms that the IADR system has performed well, has required minimal maintenance, and has effectively resolved the problems that have plagued the school. It confirms that the school system plans to retrofit the remaining conventional systems once funding can be allocated. 


\section{INSTALLATION COST COMPARISON: IADR VAV vS. CONVENTIONAL SYSTEMS}

The most common response from design engineers who are challenged with providing designs that accommodate the ventilation codes and standards intended to maintain an acceptable IAQ is that recovery and desiccant-based dehumidification technologies are too expensive for their projects. Every school district would like to have a well-ventilated, humidity-controlled and energy-efficient environment, provided the construction budget would allow for it.

As part of the initial design evaluation of this pilot project, C\&M Engineering (the program consultant) concluded that an integrated system that could enable the effective application of a VVT air distribution approach to serve multiple spaces within a school facility would result in a very costcompetitive design solution.

Following the successful operation of this pilot system, a detailed cost analysis was completed to compare the baseline IADR variable-volume system with the HVAC designs most commonly applied in hot, humid climates. The installation costs for the various HVAC systems were estimated using the R.S. Means estimating manual (2002). The estimates included installation, controls, all ductwork, and mechanical equipment required to complete the various designs analyzed.

The systems analyzed included

- Conventional rooftop units for each classroom, oversized to accommodate the outdoor air load, and with no energy recovery (low-cost benchmark).

- Conventional rooftop units for each classroom, including recovery modules.

- Water-source heat pumps for each classroom with a refrigeration-based $100 \%$ dedicated outdoor air unit.

- Water-source heat pumps for each classroom with a total energy recovery module (no coils included) allocated to precondition the outdoor air to the school facility.

- The IADR (Revolution) unit with the integrated energy recovery module, operated as a VVT system conditioning multiple spaces.

Table 4 summarizes the findings that resulted from this cost analysis. The analysis concluded that the IADR system provided the best humidity control and the lowest operating cost of all the systems evaluated. Unexpectedly, the analysis also concluded that the IADR system, including the recovery module, provided the lowest first-cost alternative of all options considered.

It concluded that school facilities and designers can easily afford to incorporate the IADR approach when it is applied as a VAV system because it does not require a cost premium over other less-effective HVAC systems. The benefits outlined in Sections 2.3 and 5 of this report can be realized, the ventilation code requirements can be easily accommodated, and an exceptional return on investment will result. The only barrier remaining is the willingness of the design engineer or building owner to consider an alternate design approach. As a result of the support of ORNL and DOE, this field demonstration pilot should provide valuable information to encourage school designers to consider this alternate approach in the future. 
Table 4. Comparison of costs of the IADR and conventional rooftop units

Summary of Results from Installed Cost Comparison

\begin{tabular}{|c|c|c|c|c|}
\hline System approach & Cost $10,000 \mathrm{ft}^{2}$ & Cost $/ \mathrm{ft}^{2}$ & Operating cost $/ \mathrm{ft}^{2}$ & Humidity control \\
\hline Rooftop and ERV & $\$ 170,590$ & $\$ 16.6$ & Fair & Fair \\
\hline WS Heat Pump and ERV & $\$ 130,055$ & $\$ 13.0$ & Fair & Fair \\
\hline Revolution and VAV & $\$ 100,950$ & $\$ 10.2$ & Lowest & Best \\
\hline \multicolumn{5}{|c|}{$\begin{array}{l}\text { 1. Cost of IADR unit with energy recovery ventilator provides baseline analysis cost based on actual data from Timber Ridge pilot site. } \\
\text { 2. Baseline case (Timber Ridge) is } 10,000 \mathrm{ft}^{2} \text { involving } 19 \text { zones, } 8 \text { classrooms, } 2 \text { hallways, } 2 \text { rest rooms, } 4 \text { teacher work rooms, } \\
\text { and } 2 \text { storage rooms } \\
\text { 3. All other system cost estimates are based on } 2002 \text { Means data, reviewed by two different mechanical consultants. }\end{array}$} \\
\hline
\end{tabular}




\section{CONCLUSIONS AND RECOMMENDED FUTURE WORK}

This research/demonstration installation of the integrated vapor compression-active desiccant hybrid system (IADR) was highly successful. All objectives were met, the performance exceeded expectations, and the end users are very satisfied with the results. Retrofit of the previous system was easily and quickly accomplished, and no maintenance problems have been experienced after more

than a year of operation. Low energy consumption and effective space conditioning were realized and documented.

The IAQ investigation confirmed quantitatively the qualitative improvement reported by the building occupants. Important indoor contaminants such as formaldehyde were reduced to guideline levels, and microbial problems have been eliminated. Recorded $\mathrm{CO}_{2}$ data have confirmed effective ventilation in accordance with ASHRAE 62 despite the use of a VAV air distribution system serving multiple spaces. The findings of this research program support previous findings reported by GTRI for a much larger schools investigation (summarized in Fischer and Bayer 2003).

This design approach will be duplicated and implemented as part of a much larger, newly constructed high school located in Georgia and scheduled to be completed early in 2006. This project will apply several IADR systems applied as both DOASs and complete VAV systems. Four of the systems will also be combined with on-site power generation to form an effective cooling, heat, and power site, using the rejected heat from the engine to regenerate the active desiccant wheels. 


\section{REFERENCES}

AGIH (American Conference of Government Industrial Hygienists) 1999. Annual Reports of the Committees on Threshold Limits Values and Biological Exposure Indices for Year 1999, https://www.acgih.org/Products/tlvintro.htm (pdf file, free to members, charge for nonmembers), ACGIH, Cincinnati.

ASHRAE (American Society of Heating, Refrigerating and Air-Conditioning Engineers) 1999. Ventilation for Acceptable Indoor Air Quality, Standard 62.1-2004, Atlanta.

ASHRAE (American Society of Heating, Refrigerating and Air-Conditioning Engineers) 2001. Energy Standard for Buildings except Low-Rise Residential Buildings, Standard 90.1, Atlanta.

Bayer C., S. Crow, and J. Fischer 2000. Causes of Indoor Air Quality Problems in Schools, ORNL/M-6633/R1, Oak Ridge National Laboratory, 2000.

Bayer C., R. Hendry, J. Fischer, S. Crow, and S. Hagen 2002. "Active Humidity Control and Continuous Ventilation for Improved Air Quality in Schools," in ASHRAE IAQ 2002 Proceedings, American Society of Heating, Refrigerating and Air-Conditioning Engineers, Atlanta.

Fischer J., 1996. "Optimizing IAQ, Humidity Control and Energy Efficiency in School Environments," pp. 188-203 in Proceedings of ASHRAE IAQ 1996, American Society of Heating, Refrigerating and Air-Conditioning Engineers, Atlanta.

Fischer J., C. Bayer 2003. "Report Card on Humidity Control," ASHRAE Journal, May 2003.

Fischer, J., and J. Sand 2004. Desiccant-Based Combined Systems: Integrated Active Desiccant Rooftop Hybrid System Development and Testing, ORNL/SUB-01-4000010402, Oak Ridge National Laboratory, August 2004.

GAO (General Accounting Office) 1996. School Facilities: America's Schools Report Differing Conditions, GAO/HEHS-96-103, GAO, Washington, D.C.

Gatley, D. P. 2002. "Dehumidification Enhancement for 100-Percent-Outside-Air AHUs," Heating/Piping/Air Conditioning Engineering, HPAC Engineering, Cleveland, p. 31, November 2000.

Harriman, L.G., G. W. Brunfrett, and R. Kittler 2001. Humidity Control Design Guide for Commercial and Institutional Buildings, Chapter 13, American Society of Heating, Refrigerating and Air-Conditioning Engineers, Atlanta.

R. S. Means 2002. Mechanical Cost Data, $25^{\text {th }}$ Annual Edition, Ed. Melville J. Mossman, R. S. Means, Kingston, MA, 2002.

Mumma, S., 2001. "Designing Dedicated Outdoor Air Systems," ASHRAE Journal, 23-31, May 2001.

NIOSH (National Institute of Occupational Safety and Health) 2002. NIOSH Pocket Guide to Chemical Hazards (CD-ROM), 2002-140, NIOSH, Washington, D.C.

Petrov, A. Y., J. R. Sand, A. Zaltash, J. Fischer, R. Mitchell, G. R. Weatherington 2005. "Performance Analysis of Integrated Active Desiccant Rooftop Air-Conditioning System Operating in Heating Mode," in Proceedings of IMECE2005: 2005 ASME International Mechanical Engineering Congress and Exposition, Orlando, FL, November 5-11, 2005. 


\section{ACKNOWLEDGMENTS}

SEMCO thanks DOE and ORNL for their support of this project. We also acknowledge the efforts of GTRI, Georgia State University, and C\&M Engineering, all of which contributed more than the funding would allow and were instrumental to the success of this program. 



\section{APPENDIX A}

\section{Sampling of Performance Points}

Performance example for system evaluated:

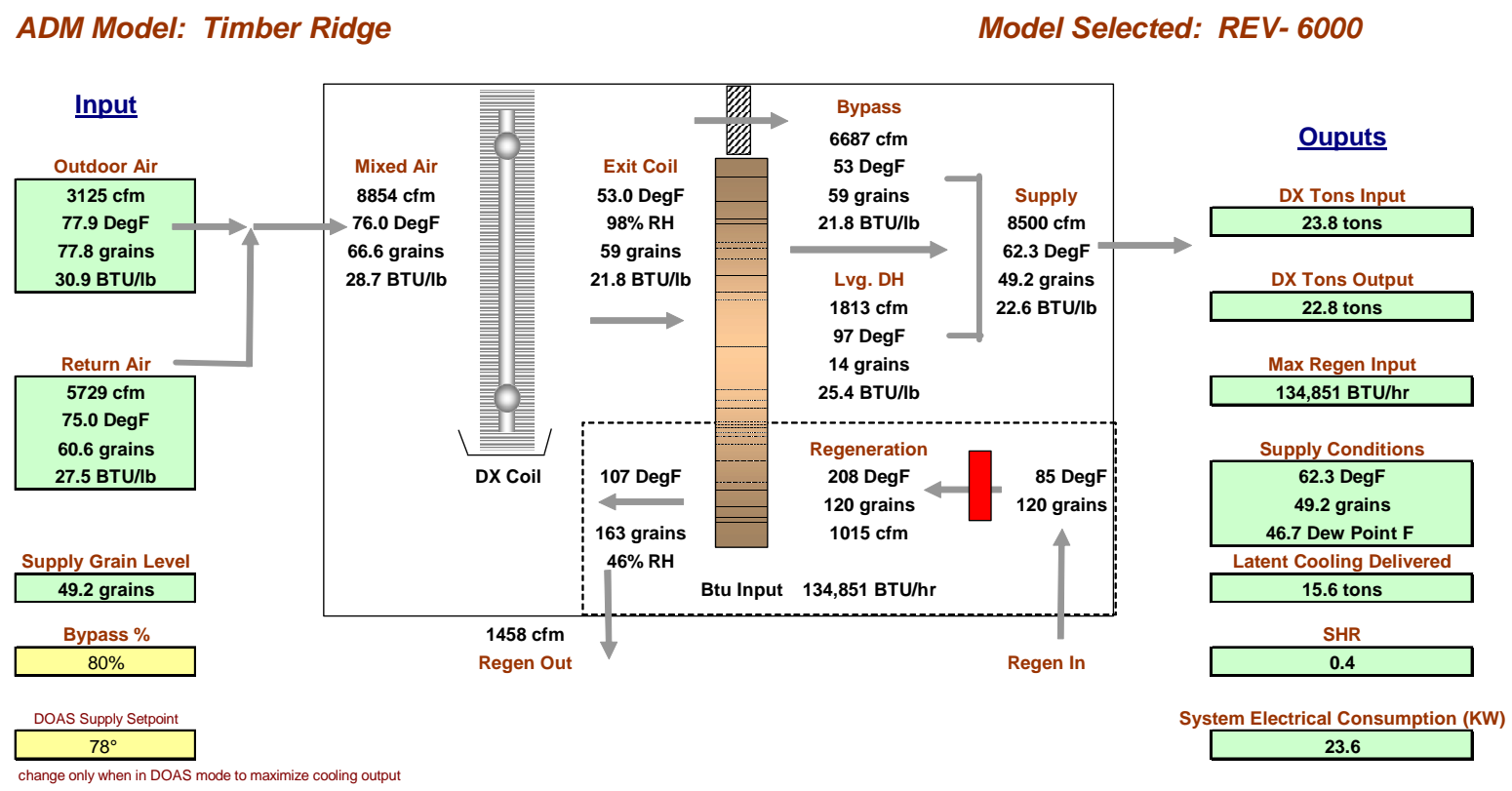

This diagram is a sampling of performance points throughout the IADR system, at design conditions, for the system applied to the Georgia school. Note that the outdoor air inlet condition shown reflects air delivered from the total energy recovery module. Also note that the supply air temperature and humidity are modulated to satisfy the needs of the space. 



\section{APPENDIX B}

\section{Letter from Cobb County School District}

The school district provided the following letter detailing the benefits of the IADR to the school system as part of the customer interview for this final report. 

October 15, 2004

Mr. Jim Sand

Program Director

Oak Ridge National Laboratory

Building 3147, MS 6070

1000 Bethel Valley Road

Oak Ridge, TN, 37831-6070

Dear Mr. Sand,

I am writing this letter on behalf of Cobb County Schools to thank Oak Ridge and the Department of Energy for co-funding the retrofit installation of the SEMCO Revolution system at our Timber Ridge Elementary school.

As you are aware, prior to the installation of the new system we had experienced numerous IAQ problems at this school. Specifically, the existing HVAC system would not allow the introduction of any outdoor air without resulting in humidity problems. These problems have been serious and have included both comfort and microbial (mold) problems over the years.

To address these problems, the outdoor air dampers of the existing rooftop units had to be closed and commercial dehumidifiers installed in many of the classrooms. This approach improved our humidity problems but resulted in IAQ and comfort complaints, noncompliance with he ventilation code and high energy costs.

The Revolution system was installed to replace one of the larger air handling units serving the section of the school that had experienced most of the IAQ and humidity problems. This area involves approximately 10,000 square feet of space made up of eight classrooms, four hallways, four teacher rooms, two rest rooms and several storage areas. 
The Revolution system is operated as a VAV system serving 19 zones. It processes both the outdoor air and return air loads, and does so without any reheat in the VAV boxes.

The Revolution system was easily installed over one weekend by our service department in conjunction with SEMCO personnel. As Energy Manager for the school district I am especially impressed that despite the fact that the unit now delivers the amount of outdoor air required by code and delivers excellent temperature and humidity control (all of which have been monitored), the energy consumption of this system is far less than that used by the conventional packaged unit that it replaced. In fact the same electrical and gas feed that served the original unit was used for the new system.

The Revolution system has now operated over one heating season, one cooling season and one summer shutdown. We have experienced excellent IAQ and comfort conditions at all times. The reliability of the system has also been excellent and it integrated perfectly with our current DDC control system.

As you may recall, we initially had concerns regarding the use of another active desiccant system since we had to remove several such systems from our schools over the years due to odor carryover problems. The testing conducted as part of this program by Georgia Tech prior to the installation eased the concerns stressed by our Superintendent. Subsequent air quality testing completed at Timber Ridge by Georgia Tech has confirmed that the indoor air quality in the areas served by the new system has been improved significantly and is now very acceptable. Most importantly, the teachers are very happy with the new system.

The results of this retrofit have been so positive that we now pressured to address the remainder of the school. Unfortunately, like many school districts we are under a very tight budget this year so we have not yet been able to fund a program to replace the rest of the rooftops with Revolution systems. However when funds do become available we hope that we will be able to do so.

I am happy to be able to provide such positive feedback to DOE for this pilot program. The new technology has proven to be an excellent system that enables schools to provide a cost effective way to meet the ventilation code requirements, control space humidity and minimize operating costs.

If I can answer any questions that you may have please feel free to contact me directly,

Sincerely,

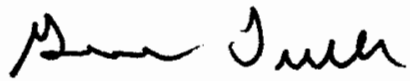

Gene Trull

Cobb County Schools

Maintenance Supervisor/HVAC

Cc: Steve Daniel 
ORNL/Sub-01-4000025209

\section{INTERNAL DISTRIBUTION}

1. M. A. Brown

2. R. B Shelton

3. R. C. DeVault

4. Patricia Garland
5. E. C. Fox

6. D. P. Stinton

7- J. R. Sand

29.

30. Office of Technical Information and Classification

\section{EXTERNAL DISTRIBUTION}

31. Ren Anderson, National Renewable Energy Laboratory, 1617 Cole Blvd., Golden, CO 804013393

32. Frank Ballistreri, Reliant Energy-Minnegasco, P.O. Box 59038, 800 LaSalle Avenue, Minneapolis, MN 55459-0038

33. Douglas Bauer, Commission on Engineering and Technical Systems, National Research Council, Harris 280, 2001 Wisconsin Avenue NW, Washington, DC 20007

34. John Fischer, SEMCO, Inc., 737 Terrell Crossing, Marietta, GA 30067

35. Ronald Fiskum, Office of Distributed Energy and Electricity Reliability (EE-2D), U.S. Department of Energy, 1000 Independence Avenue SW, Washington, DC 20585

36. Arthur D. Hallstrom, Air Handling Systems, The Trane Company, 1500 Mercer Road, Lexington, KY 40511

37. Lew Harriman, Mason-Grant Consulting, P.O. Box 6547, 57 South Street, Portsmouth, NH 03802

38. Patricia Hoffman, Office of Distributed Energy and Electricity Reliability (EE-2D), U.S. Department of Energy, 1000 Independence Avenue SW, Washington, DC 20585

39. Deborah Haught, Office of Distributed Energy and Electricity Reliability (EE-2D), U.S. Department of Energy, 1000 Independence Avenue SW, Washington, DC 20585

40. David C. Kalensky, Energy Utilization Center, Gas Technology Institute, 1700 S. Mount Prospect Rd., Des Plaines, IL 60018-1804

41. John Kelly, GTI, 17090 South Mount Prospect Road, Des Plaines, IL 60018-1804

42. Douglas R. Kosar, University of Illinois-Chicago, Energy Resources Center (MC 156), 851 S. Morgan St. (SEO Room 1222), Chicago, IL 60607-7054

43. William A. Ryan, University of Illinois-Chicago, Energy Resources Center (MC 156), 851 S. Morgan St. (SEO Room 1222), Chicago, IL 60607-7054

44. Steven Slayzak, Center for Buildings and Thermal Systems, National Renewable Energy Laboratory, 1617 Cole Blvd., Golden, CO 80401-3393

45. Richard S. Sweetser, EXERGY Partners Corporation, 12020 Meadowville Court, Herndon, VA 20170

46. William M. Worek, University of Illinois-Chicago, Energy Resources Center, 851 South Morgan Street, 1207 SEO, Chicago, IL 60607-7054

47. Jaroslav Wurm, 2453 S. 4th Ave., N. Riverside, IL 60546 